\title{
Profits, Innovation and Financialization in the Insulin Industry
}

\author{
Rosie Collington*
}

\section{Working Paper No. 120}

\author{
March 30 ${ }^{\text {th }}, 2020$
}

\begin{abstract}
The list prices of analogue insulin medicines in the United States have soared during the past decade. In the wake of high-profile cases of prescription medicine "price-gouging", such as Mylan's EpiPen and Turing-acquired Daraprim, actors across the insulin supply chain are today facing growing scrutiny from US lawmakers and the wider public. For the most part, however, the role of shareholders in the insulin supply chain has been overlooked. This paper considers the relationship between profits realized from higher insulin list prices, pharmaceutical innovation, and the financial structures of the three dominant insulin manufacturing companies, which set list prices. It shows that despite claims to the contrary, insulin manufacturers extracted vast profits

* University of Copenhagen and the Academic-Industry Research Network.

The Institute for New Economic Thinking provided funding for this research through a grant to the Academic-Industry Research Network. The paper could not have been written without the guidance of Professor Bill Lazonick, who has provided invaluable support from across the Atlantic since I first got in touch with preliminary data on insulin pricing and total shareholder payout almost a year ago. The arguments made have benefitted from conversations with Öner Tulum and Toke Dahler, and the razorsharp eye of Ken Jacobson. Fred Ledley MD and his team at the Center for the Integration of Science and Industry at Bentley University, Massachusetts, have offered important feedback and insights. Thanks also to Adam Bouyamourn for comments on the pricing calculations included in an earlier version of the paper. Any shortcomings remain, of course, my responsibility.
\end{abstract}


from the sale of insulin products in the period 2009-2018, as insulin list prices rose. Distributions to the company shareholders in the form of cash dividends and share repurchases totaled $\$ 122$ billion over this period. The paper also considers the role of other actors in the insulin supply chain, such as pharmacy benefits managers (PBMs), in the determination of list prices. The data and analysis presented in the paper indicates that financialization could be considered in tension with not only the development of new drugs that will be available to patients in the future, but also the affordability of products that already exist today.

\section{https://doi.org/10.36687/inetwp120}

JEL Codes: D22, D53, G32, I11, L11, O32

Keywords: innovation; financialization; pharmaceutical industry; insulin; corporate governance, share buybacks. 


\section{Table of Contents}

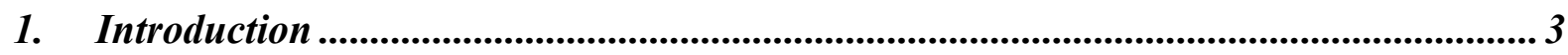

2. How much has the price of insulin changed in recent years?.......................................... 6

Do insulin manufacturers benefit from list price increases? ........................................................ 8

Figure 2.1. Net revenue from insulin products at Eli Lilly, Novo Nordisk and Sanofi, 2009-2018............. 9

3. How do insulin manufacturers distribute profits? ...........................................................9

Distributions to shareholders and R\&D costs ................................................................................... 10

Table 3.1. Revenue, net income, and distributions to shareholders, major insulin manufacturers, 2009-2018

Figure 3.1. Ratio of R\&D spending to external TSP, 2009-2018

Figure 3.2. Distributions of share repurchases and cash dividends at Eli Lilly, Novo Nordisk and Sanofi, 2009-

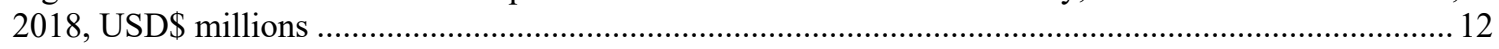

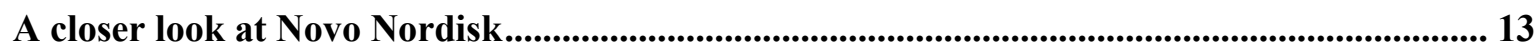

Figure 3.3. Novo Nordisk sales to North America versus rest of the world, 1999-2018 ......................... 13

Figure 3.4. R\&D spending versus total shareholder payout at Novo Nordisk, 1999-2018 ....................... 14

Figure 3.5. Novo Nordisk share adjusted close price, 1999-2018 …..................................................... 15

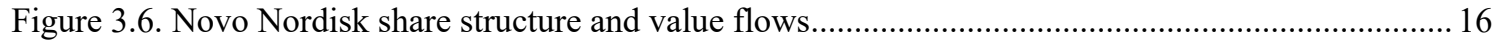

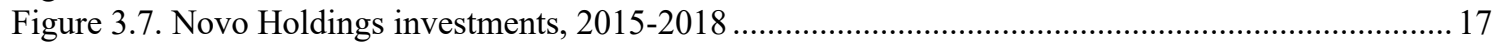

4. Which other actors in the insulin supply chain benefit from list price increases?..... 19

Figure 4.1. The pharmaceuticals supply chain in the United States ...................................................... 19

The beginning: the role of the government sector in the development of insulin ..................... 19

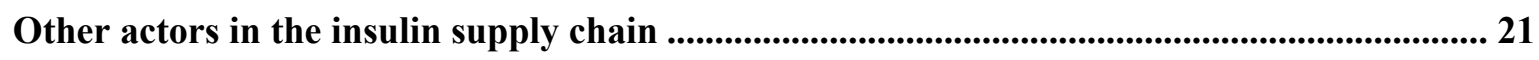

5. Conclusions and directions for further research .......................................................24

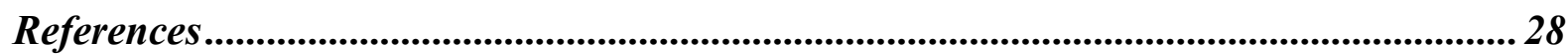




\section{Introduction}

For type-1 diabetics, inability to access insulin can be fatal. Type- 1 diabetes is an autoimmune condition that leads to kidney failure, blindness and diabetic ketoacidosis (DKA) if left untreated. Insulin is a hormone that is used to control the high blood glucose levels associated with type-1 diabetes. Insulin can also be used as a treatment for type-2 diabetes, although in many countries it is not used as a first line therapy (NICE, 2020). The Centers for Disease Control and Prevention (CDC) estimated that as of 2018, 10.9\% of all adults resident in the United States with diagnosed diabetes started using insulin within a year of their diagnosis (CDC, 2020, p. 4).

Throughout most of the twentieth century, insulin was produced solely by extraction from animal pancreases, where it naturally occurs. Since the 1970s, it has been possible to produce insulin synthetically, and the human insulin products developed in the 1970s using government-funded research drastically improved treatment outcomes and patients' ability to manage their condition.

Today, approximately 1.25 million adults and children live with type-1 diabetes in the United States (American Diabetes Association, 2019). The insulin analogues that were developed between the late-1990s and the mid-2000s continue to be the most widely used insulin products today among type-1 diabetes patients in the United States (Pharmaceutical Technology, 2016), as they are purported to provide patients with greater control and accuracy in the management of their blood glucose levels than earlier insulin formulations. It is worth noting that a recent Cochrane Review suggests that the clinical advantage of short-acting analogue insulin medicines over earlier insulin formulations are minor (Fullerton et al., 2016). Analogue insulin medicines also include fast-acting, slow-acting, intermediate-acting and long-acting formulations, which are produced primarily by three companies. Between them, Eli Lilly (United States), Novo Nordisk (Denmark) and Sanofi (France) control 99\% of the insulin market (Cefalu et al., 2018).

The list prices of analogue insulin medications in the United States have soared in recent years (Fuglesten Biniek and Johnson, 2019, pp. 7-9; Lee, 2019; Ramsey, 2017). The three companies that manufacture insulin have come under growing scrutiny from regulatory bodies and Congress for their role in what has been labeled medicine "price-gouging", and its detrimental effects on access for diabetes patients. Patients in the United States usually access prescription medicines through their health insurance provider but are required in most cases to pay for a proportion of the treatment themselves. A growing number of US citizens are not covered by a health insurance plan and rely instead on out-of-pocket payments. Costs for branded (non-generic) medications can thus become very expensive for patients, where the list price is set by the manufacturer that holds market exclusivity rights.

Until last year, no alternative to the high-priced branded analogue insulin medications existed. ${ }^{1}$ The companies that produce insulin had argued for a long time that as a biologic, analogue insulin medicines were more expensive to produce than other pharmacological products (Ramsey, 2016a), and that this justified their higher list prices - and higher costs to insurance plan providers and/or patients. This argument was challenged in the years leading up to the introduction of Eli Lilly's

\footnotetext{
${ }^{1}$ Elsewhere, such insulin products have been referred to as 'generic' insulin products, but this term is incorrect. Insulin is a biologic, and it is therefore not possible to produce a product that is chemically identical to the analogue insulin products produced by Eli Lilly, Novo Nordisk and Sanofi.
} 
cheaper alternative analogue insulin medication in May 2019, with one study suggesting that "it may be possible to profitably manufacture biosimilars of recombinant human insulin and insulin NPH for a price of USD\$72 per patient per year or less" (Gotham et al., 2018, p. 5).

Towards the end of 2019, Novo Nordisk also announced that it would offer a cheaper version of its branded insulin medicine Novolog at $50 \%$ of its current list price in the United States the following year (Novo Nordisk, 2019a). Eli Lilly has since committed to introducing further cheaper versions of its branded products to the market, also at lower list prices (Eli Lilly, 2020). It is important to point out that these products are neither technically 'generics' nor 'biosimilars'; they are existing, approved products launched under a different name at a lower list price. This sequence of events, where hiking the list price of branded medicines precedes the introduction of generic, biosimilar or lower-priced versions of existing products, has parallels in the case of Mylan's EpiPen. The price for a pack of two EpiPens, used as a treatment for severe, lifethreatening allergic reactions, increased by 548\% from 2007 to 2016 to $\$ 608.61$ (Rockoff, 2016). In 2012, the company had settled a lawsuit agreeing to permit a generic competitor into the market, and it was after then that the company began to increase the list price at a faster rate (Milford, 2012). At its peak, a spokesperson for Express Scripts, a pharmacy benefits manager, speculated that the company was pricing the medicine "as high as they can for as long as they can" (Pollack, 2016). In other words, increasing the list price was a means of inflating profits before a generic version of the medicine was introduced. Generally, when a generic version of a medicine is introduced to a market, the company that manufactured the branded version sees its revenue from that product fall over time.

The introduction of a generic, biosimilar or lower-price version of an existing medicine to a market heretofore dominated by expensive patented products is not necessarily a panacea for patients, however. These versions of medicines can also be expensive, and potentially prohibitively so for many patients. The list price of generic medicines tends to be higher in the United States than in other countries (Sarnak et al., 2017; U.S. Government Accountability Office, 2016). By the end of 2017, the two generic EpiPens now on the market, produced by Teva and Mylan, were listed at $\$ 300$ for a pack of two - three times what the branded version had been listed for in 2007 (Reuters, 2018). In the case of analogue insulins, the promised 50\% lower list price of the cheaper re-branded version of Eli Lilly's Humalog, which the company says will be available from April 2020, is more than double the list price of Humalog when it was launched in 1996 (Ramsey, 2016b). Whether the generic, biosimilar or lower-price version of an existing medicine can be considered to have a lower list price than the higher-priced branded version therefore depends ultimately on which price point of the branded product, at which point in time, one compares the generic price point to.

A further reason why the introduction of a generic, biosimilar or lower-priced version of an existing medicine may not significantly alter the market distribution of branded products in the US health system can be found in the central role played by marketing and distribution channels in the availability of medicines. Manufacturers expend resources on marketing and negotiate agreements with other actors in the medicine supply chain to ensure their products secure the widest, most lucrative possible share of the market (Naci et al., 2015; Søndergaard et al., 2009). Marketing decisions and resource commitments influence which products patients are prescribed and have access to, and it may well be that insulin manufacturers are not promoting the cheaper re-branded analogue insulin options to pharmacies, physicians and patients in a way that drives up the share 
of those products in the market. Companies do not, of course, publish details of their marketing strategies, but a survey conducted by the offices of Senators Elizabeth Warren and Richard Blumenthal in December 2019 found that in $83 \%$ of the 386 pharmacies surveyed across all states, the cheaper re-branded version of Eli Lilly's Lispro was not in stock and available for patients (United States Senate, 2019, p. 1). Further research is needed to evaluate utilization of biosimilar or cheaper re-branded analogue insulin products as they become available on the market, and in the meantime, it is important that policymakers and the public do not assume the introduction of these products will automatically remedy concerns over access to insulin in the United States, as suggested - among others - by Representative Mike Kelly in his call for the enactment of the Market Access for Generic Insulin Competition (MAGIC) Act of 2019 (Kelly, 2019).

The developments described above point to a need for an understanding of how pharmaceutical companies determine medicine list prices, to what uses the profits from higher list prices are distributed, and how actors across the medicines supply chain influence pricing decisions. Taken together, the answers to these questions can tell us why a company decides to increase a medicine's list price, despite intense political and public scrutiny, as in the case of insulin. Through an exploration of the interests in and corporate governance of the analogue insulin market at this critical juncture in its evolution, this paper offers a contribution to such an understanding. It asks: How much have insulin prices increased in the United States? Who has benefitted from higher insulin list prices? Where have the rising profits flowed? Its developing supposition is that while various actors in the insulin supply chain have profited from higher list prices, notably pharmacy benefits managers (PBMs), it is the shareholders of the three manufacturing companies that have reaped the most disproportionate gains, through the extraction of value via cash dividends and rising expenditure on share repurchases in the companies, which to varying extents prioritize maximizing shareholder value at the expense of patient access and actual treatment innovation (Lazonick et al., 2016; Lazonick and O'Sullivan, 2000). In the case of one company, Novo Nordisk, shareholders include a non-profit industrial foundation, which endows Novo Nordisk with relative corporate stability through the development of long-term capital (Thomsen et al., 2018). The paper suggests nonetheless that this model of financing has not undermined shareholder interest in insulin list price increases. The financialization of insulin-manufacturing companies could thus be considered in tension with not only pharmaceutical innovation and the development of future treatments for patients, but also the affordability of products that are on the market now.

The discussion in the remainder of this paper is structured in three parts. It begins by considering the contention that manufacturing companies have not benefitted from analogue insulin list price increases. I present data supporting the findings of a recent study by Hernandez et al. (2020), showing that over the period 2009-2018, the analogue insulin manufacturing companies saw net revenue from insulin that was far higher than what would have been expected if they had not benefitted from price increases of insulin. Then, I analyze how the higher profits from insulin sales are distributed by the companies, presenting data indicating that where direct R\&D expenditure ratios have decreased since 2009, distributions to shareholders have increased. These findings reflect data produced by Lazonick, Tulum and colleagues (2019, p. 4) on the wider US pharmaceutical sector, and indicate that the insulin firms, too, operate on the basis of a financialized corporate governance model. 
The paper then considers Novo Nordisk in detail, exploring whether its industrial foundation model of corporate governance could serve to limit company and group interests in increasing insulin formulation list prices. It suggests that while the industrial foundation model may provide a degree of stability relative to other corporate governance models through ensuring access to longterm finance, it has not reduced the extent to which the company has stood to benefit from insulin list price increases and thus does not necessarily render the firm more innovative. Some of Novo Nordisk's profits have been transferred to Novo Holdings in the form of cash dividends and share repurchases, which finance investments in small- and medium-sized biotech companies. Novo Holdings also makes liquid investments, comprised predominantly of equities. The Novo Group's corporate governance model thus provides it with access to long-term finance for future investment in innovation. However, the main source of that long-term finance in recent years has been higher profits from list price increases of insulin formulations in the United States. Higher profits have thus been used to fund SMEs, but the price has been to make a life-or-death medicine unaffordable and inaccessible to many patients in the United States.

In the final part of the paper, I outline the complex array of actors that regulate and participate in the supply chain of insulin, evaluating to what extent and how each may benefit from higher drugs list prices, and thus influence pricing decisions. This analysis leads to a discussion on directions for future research that builds on the knowledge and data presented in this paper.

Although some large pharmaceuticals-producing companies are today moving away from describing themselves as 'pharmaceutical companies', I use this term to delineate between the long-established companies, which includes the three that are the focus of this paper, and the 'biotech' industry. It is widely accepted that this latter term refers to drug discovery and gene therapy companies founded since the 1970s (Owen and Hopkins, 2016, p. 9; Pisano, 2006). My use of the term 'insulin industry' refers to the three dominant insulin-manufacturing companies: Eli Lilly, Novo Nordisk and Sanofi.

\section{How much has the price of insulin changed in recent years?}

The mean price paid by patients for insulin in the United States almost tripled between 2002 and 2013 (Hua et al., 2016, p. 1401). More recent analysis from the Health Care Cost Institute using health care claims data estimates that per-person spending on insulin by patients and insurance plans in the United States doubled between 2012 and 2016, despite only a marginal increase in insulin use (Fuglesten Biniek and Johnson, 2019, p. 4). A study of changes in the list prices of branded drugs in the United States found that insulin list prices increased by $262 \%$ between 2007 2018 (Hernandez et al., 2020).

In the context of the United States pharmaceutical supply chain, list prices are the prices set by the manufacturer for the medicine. Patent protection rules allow drug manufacturers to secure 20 years of intellectual-property exclusivity not only for novel treatments, but also drugs that are variations of existing treatments and tend to require relatively lower research and development costs and lead times (Roy and King, 2016; UCL Institute for Innovation and Public Purpose, 2018). Special protections also exist in the United States for certain areas in the pharmaceutical market, such as those granted under the Orphan Drug Act of 1983 (ODA), which grants financial subsidies and market exclusivities for the development of drugs for rare and genetic diseases (Lazonick and Tulum, 2011). The ODA has until now not been an important factor in insulin pricing, though this 
may well change with the era of precision medicine and research exploring genetic risk factors in type-1 diabetes patients (Brissova et al., 2018; Mattner et al., 2019; Pesenacker et al., 2019).

The relative lack of price regulation for prescription medicines in the United States is important for understanding insulin list price increases and drug pricing in general. There is no upper threshold for the price of branded medicines in the United States. This lack of price regulation has implications for not just individuals with private health insurance and those with no insurance but also those covered by Medicare and, to some extent, Medicaid. Although Medicare has some discretion in the determination of prices it pays for prescription drugs, financing more than a quarter of prescription expenditures, at present only the Veterans Health Administration and the Department of Defense are formally allowed to negotiate prices directly with drug manufacturers. The Prescription Drug Price Relief Bill, introduced in October 2019, would enable the Department of Health and Human Services (HHS) to review at least annually all brand-name drugs for excessive pricing if enacted (Sanders, 2019). Mandatory drug price rebates also exist for Medicaid (True et al., 2019).

The absence of price controls has come under growing scrutiny in recent years following highprofile cases where companies increased the price of long-established patented medicines for no discernible motive other than to increase profits. These cases include the decision by Turing to increase the price of its newly acquired, but 65-year-old, antiparasitic drug Daraprim overnight from $\$ 13.50$ to $\$ 750$ per pill (Pollack, 2015). Put simply, weak drug price controls mean that if the executives of a drug manufacturer decide to increase the list price of a drug - for whatever reason - they can do so, regardless of its implications for patient access. That it was legal for the Turing CEO to increase the price of a decades-old product by 5,500\% overnight reflects the failure of conventional economics to explain the nature of the forces involved in drug pricing; there was no change in the demand for nor supply of Daraprim in the period before its price soared.

The amount that individuals pay for their insulin prescription depends on their health insurance plans, whether provided by an employer, individual subscription, Medicaid or Medicare. Although patients covered by insurance plans tend not to pay the full list price for their prescription medicines, increases in list prices for prescription medicines can result in higher costs of insurance coverage in the form of deductibles, co-pays and premiums. A Kaiser Family Foundation report from 2019 indicated that premiums for health insurance coverage across the country have grown at a rate that exceeds wage growth over the past five years. For the period 2014 to 2019, the average premium for family coverage increased by $22 \%$ while earnings for this group was just $14 \%$ with overall inflation at 8\% (Kaiser Family Foundation, 2019, pp. 30-42). The same report showed that the share of insured individuals who pay a deductible has also increased, and the average annual deductible among those workers with a deductible grew by $36 \%$ over the last five years (ibid., $\mathrm{p}$. 108).

Despite an overall reduction in the number of uninsured Americans following the introduction of the Accountable Care Act (ACA) in 2010 (Tolbert et al., 2019, p. 2), there remain many individuals who are not covered by an insurance plan, particularly in the 19 states that have not opted to expand Medicaid to low-income Americans, as called for in the ACA (CDC, 2019). In most cases, uninsured individuals need to pay out-of-pocket for healthcare costs. Many prescription medicines are too expensive for those without health insurance, and these individuals are more likely than 
those with insurance to report cost-associated nonadherence (Kennedy and Morgan, 2006). A recent study found that one in four of the diabetes patients experienced cost-related nonadherence to insulin medicines (Herkert et al., 2019). Reports from patient organization T1International indicate similar affordability problems, with numerous reports of type-1 diabetes patients dying after rationing their prescription of insulin (T1International, 2019). Rationing insulin can lead to serious medical complications, which can be fatal if left untreated. Socioeconomic factors have been found to be important in DKA admissions (Randall et al., 2011). These findings suggest that higher prescription medicine costs, which can result from higher list prices, have serious consequences for patients.

\section{Do insulin manufacturers benefit from list price increases?}

The list price of a medicine in the United States is usually not what the manufacturer actually receives, as a range of other actors also receive a share of the payments. The net price that manufacturers receive is the list price "less any fees paid to wholesalers, and/or discounts paid to pharmacies, and any rebates paid to PBMs or health plans" (Cefalu et al., 2018a, p. 3). The gap between a medicine's list price and net price is impossible to estimate in most cases, however, as pharmaceutical companies do not generally publish data on the net prices.

The American Diabetes Association's Insulin Access Working Group has reproduced data released by Novo Nordisk, which indicate that for certain insulin products, the net price of insulin has grown at a slower rate in recent years than the list price of insulin. This gap suggests that the pharmaceutical companies that manufacture insulin are not the main beneficiaries of list price increases, and that other actors in the insulin supply chain may have an important role to play in increasing the price of insulin. The data show that the compound annual growth rate (CAGR) for the list prices of Novo Nordisk's NovoLog and NovoLog Flexpen have been in the range of 9.8$9.9 \%$, while the CAGR for the net prices received by the manufacturer increased at a CAGR of 0.2-2.1\% (Cefalu et al., 2018a, 2018b). The Wall Street Journal similarly reported in 2016 that while the net price of Sanofi's Lantus had increased more or less in parallel with the list price from 2007-2013, the net price growth rate decreased between 2014 and 2016 (Loftus and Roland, 2016).

At the time of writing, the companies have not published data on the pricing of their wider insulin product lines. Pricing practices are trade secrets, leaving open the option for companies to be selective about the data they do publish. Nonetheless, a recent study published in JAMA provides data suggesting that the figures above, released by Novo Nordisk and published in the Wall Street Journal, may not be representative of wider insulin product line pricing. Hernandez, San-JuanRodriguez and Good (2020) find that the net prices of seven branded insulin products increased by $51 \%$ between $2007-2018$. Although this increase was not as high as the list price increase for the same group of products $(262 \%)$, it is nonetheless far higher than one would expect if the manufacturers had made no additional net revenue from insulin during a period when its list price had soared, even when inflation, population growth, diabetes prevalence and estimated per capita use growth rates (Fuglesten Biniek and Johnson, 2019, p. 4) are accounted for.

Data available from the financial reports of the companies similarly show that the three companies saw annual net revenue from insulin products that was on average $44 \%$ higher than 2009 for the years 2010-2018. This is summarized in Figure 2.1. 
Figure 2.1. Net revenue from insulin products at Eli Lilly, Novo Nordisk and Sanofi, 2009-2018

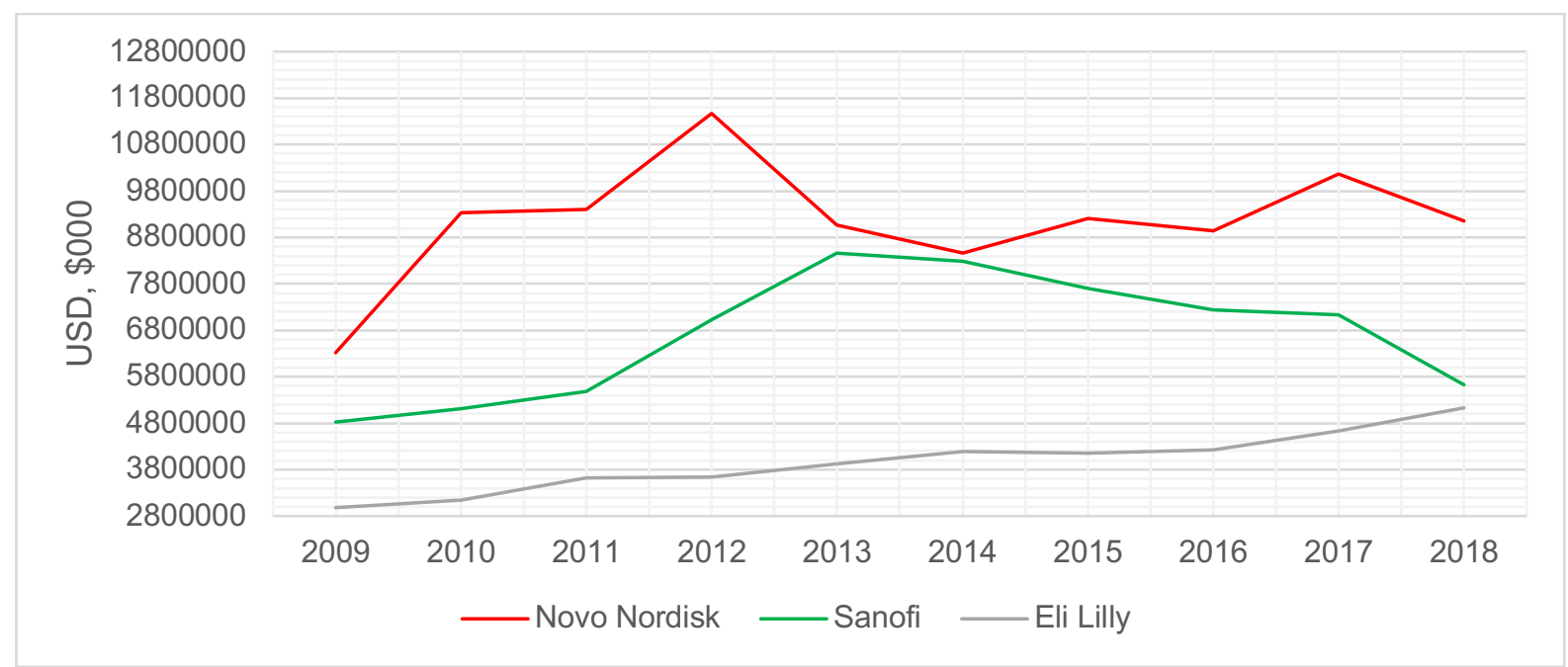

Data source: Bureau van Dijk/Moody's; company annual reports 2009-2018

The sharp climb in net insulin sales revenues between 2009-2012 reflects data suggesting that insulin list price increases were particularly high during this period (Lee, 2019). These data, publicly available in the companies' financial reports, thus support the findings of Hernandez, SanJuan-Rodriguez and Good (2020), indicating that insulin manufacturers have benefitted from list price increases. The remainder of this paper is dedicated to exploring how the profits of the major insulin companies have been distributed, and, then, which actors beyond insulin manufacturers may have benefitted from list price increases.

\section{How do insulin manufacturers distribute profits?}

The profits that a company makes from the sale of its products can be the foundation for innovation, funding investment in plant and equipment, research and development, and training and engaging workers as stakeholders in the company's growth (Lazonick, 2015; Lazonick et al., 2017a, p. 12). In pharmaceutical companies, profits fund the development of new medicines. In contrast to the tenets of neoclassical orthodoxy, productive firms are therefore those that invest in innovative capabilities and organizational learning (Lazonick, 2020; Penrose, 2009), and not those that seek to maximize shareholder value by increasing distributions to shareholders through cash dividends and share repurchase programs (Lazonick and O'Sullivan, 2000). The neoclassical view that the most successful firm maximizes value for shareholders in part by cutting the costs of production has come to dominate corporate governance thinking in the United States and beyond (Friedman, 1970; Jensen, 1986; Schuster, 2000). As Lazonick (2016, p. 100) puts it in his critique of shareholder-value ideology, the argument "is that, of all participants in the business corporation, shareholders are the only economic actors who make productive contributions without $a$ guaranteed return". By this logic, neoclassical economists contend that only shareholders have a claim on profits if and when they occur, thus justifying the boosting of corporate profits through cost-cutting and the draining of corporate cash through dividends and buybacks (ibid., p. 100-101). 


\section{Distributions to shareholders and R\&D costs}

Pharmaceutical industry actors have long argued that high drug prices are needed to augment investment in innovation. The industry has attributed the growing list prices of many new medicines to what it claims are higher costs of developing a drug (PhRMA, 2019). A study partially funded by drug manufacturers suggested, for example, that the total cost of developing a drug and getting it approved in 2014 was $\sim \$ 2.6$ billion, a figure that was three times the estimate produced by the same research group in 2001 of $\$ 802$ million (DiMasi et al., 2016; Harris, 2001; Millman, 2014). Other studies have examined the 'efficiency' of R\&D spending in recent years. Scannell et al. (2012, p. 192), for example, indicate that the number of new drugs approved per billion US dollars spent on R\&D has halved roughly every nine years since 1950 . It has also been suggested that increasing production costs have forced companies to increase list prices (Malerba and Orsenigo, 2015, p. 678). There is no doubt that the cost of developing, manufacturing and acquiring approval for a new drug is high, and that it has grown since the post-1945 period, when many of the 'blockbuster' drugs still in use today were first introduced and safety regulation was relatively lax. But exactly how high this cost is, and the extent to which the rate of list price increases matches increases in R\&D spending, is worthy of investigation; one would expect a company's increasing revenue from product lines with rising list prices to be matched by increases in its R\&D spending on new drug development. In the case of insulin, manufacturers' own financial data do not support this hypothesis. In 2018, total R\&D spending across all three companies was only $\$ 1.8$ billion higher than it had been in 2009. Over the nine-year period 2010-2018, the average additional amount spent on R\&D per annum relative to 2009 figures was $\$ 834$ million. During the 2009-2018 period, net income was equal to $\sim 15-30 \%$ of net revenue, a figure that steadily increased.

The question of whether high drug prices are necessary to fund increased R\&D spending can also be addressed by analyzing the allocation of corporate profits. To understand where the companies might be distributing profits from the sale of insulin products, we need to turn to the companies' financing cash flows. Table 3.1 below shows that for the total period 2009-2018, Eli Lilly, Novo Nordisk and Sanofi collectively distributed a total of $\$ 122$ billion to shareholders in the form of share buybacks and cash dividends. Cash dividends are the means used by publicly listed firms to distribute money to shareholders as a reward for holding shares. Buybacks done as open-market repurchases offer a way for share sellers to time the sale of existing shares at higher prices. Corporate executives, investment bankers and hedge-fund managers time their stock buying and selling to reap gains, using access to non-public information about company repurchasing activity (Lazonick et al., 2017b, p. 4).

Table 3.1. Revenue, net income, and distributions to shareholders, major insulin manufacturers, 2009-2018

\begin{tabular}{|c|c|c|c|c|c|c|c|c|c|c|c|}
\hline Company & $\begin{array}{c}\text { iREV } \\
\$ b\end{array}$ & $\begin{array}{c}\text { tREV } \\
\$ b\end{array}$ & $\begin{array}{l}\mathrm{NI} \\
\$ \mathrm{~b}\end{array}$ & $\begin{array}{l}\text { BB } \\
\$ \text { b }\end{array}$ & $\begin{array}{l}\text { DV } \\
\$ \text { b }\end{array}$ & $\begin{array}{c}\text { TSP } \\
\$ b\end{array}$ & $\begin{array}{c}\text { R\&D } \\
\$ b\end{array}$ & $\begin{array}{l}\mathrm{BB} / \\
\mathrm{NI} \%\end{array}$ & $\begin{array}{l}\text { DVI } \\
\text { NI\% }\end{array}$ & $\begin{array}{l}\text { TSPI } \\
\text { NI\% }\end{array}$ & $\begin{array}{r}\text { R\&D/ } \\
\text { REV\% }\end{array}$ \\
\hline Eli Lilly & 39.63 & 223.14 & 33.08 & 7.36 & 21.70 & 29.06 & 50.40 & 22 & 66 & 88 & 23 \\
\hline $\begin{array}{l}\text { Novo } \\
\text { Nordisk }\end{array}$ & 91.51 & 142.75 & 42.93 & 21.47 & 18.81 & 40.28 & 18.83 & 50 & 44 & 94 & 13 \\
\hline $\begin{array}{l}\text { Of which } \\
\text { external }\end{array}$ & - & - & - & 18.44 & 13.52 & 31.96 & - & 43 & 31 & 74 & - \\
\hline $\begin{array}{l}\text { Of which to } \\
\text { Novo Group }\end{array}$ & - & - & - & 3.03 & 5.29 & 8.32 & - & 7 & 12 & 19 & - \\
\hline Sanofi & 66.87 & 418.44 & 63.99 & 11.42 & 41.08 & 52.51 & 61.69 & 18 & 64 & 82 & 15 \\
\hline
\end{tabular}


$i R E V=$ net revenue from insulin sales; $t R E V=$ total net revenue; $N I=$ net income; $B B=$ share buybacks/repurchases; $D V=$ cash dividends; TSP = total shareholder payout (share repurchases + cash dividends), $R \& D=$ research and development Data source: Bureau van Dijk/Moody's

The ratio of $R \& D$ spending to TSP varied among the three companies, and across the ten-year period 2009-2018. By 2018, this ratio at all three companies was lower than it had been in 2009, reflecting a general decrease of the proportion of profits spent on R\&D relative to TSP over the ten years. This ratio is represented in Figure 3.1. The objective of increasing shareholder value must be considered an important factor in the companies' decisions to increase product list prices.

Figure 3.1. Ratio of R\&D spending to external TSP, 2009-2018
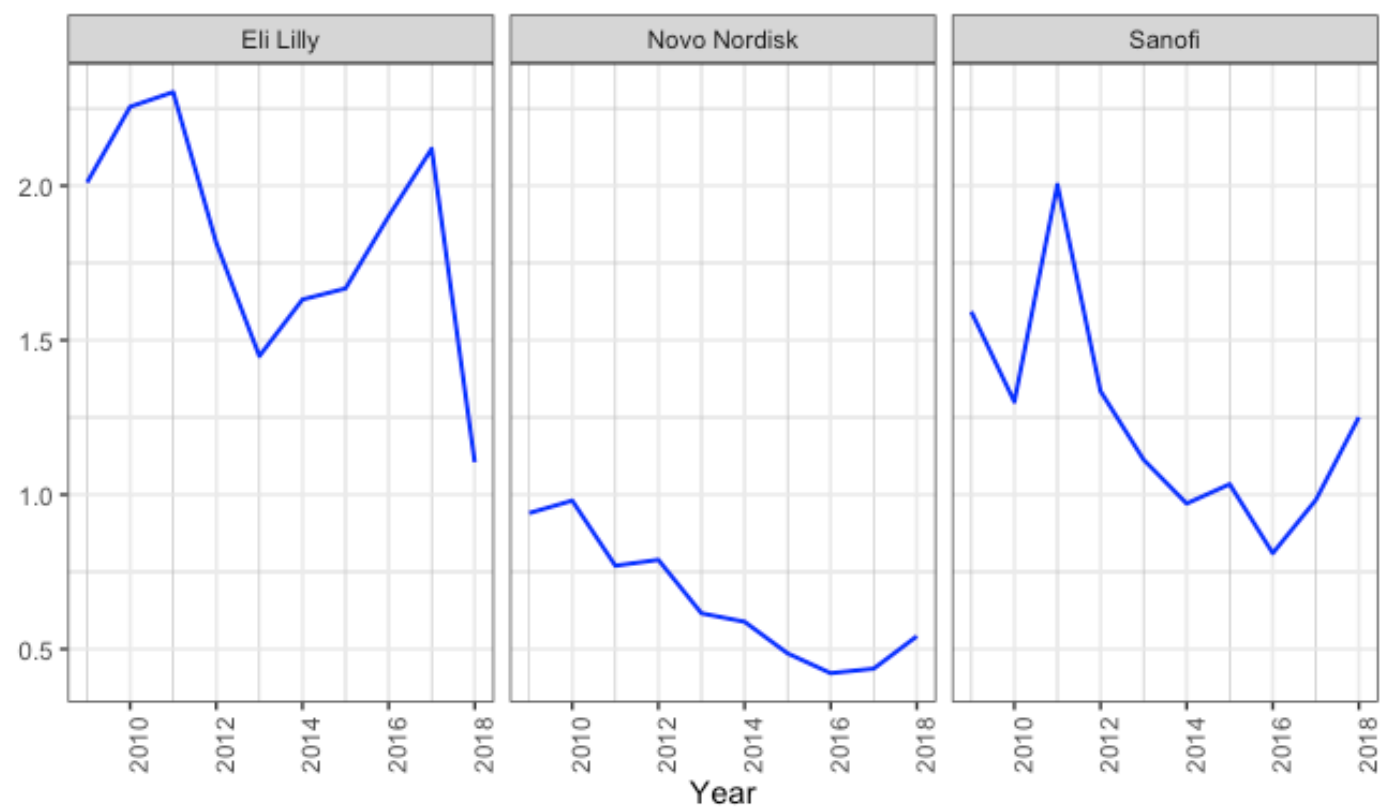

Data source: Bureau van Dijk/Moody's; company annual reports 2009-2018

Figure 3.2. below shows that the relationship between the amounts the companies distributed to shareholders in the form of cash dividends and share repurchases differed at the three companies over the ten-year period. Sanofi distributed a much higher amount of cash dividends relative to share repurchases throughout the period 2009-2018. Its distributions in the form of share repurchases spiked in 2016. At Eli Lilly, the amount distributed to shareholders in the form of cash dividends did not change significantly throughout this period, though its share repurchases varied greatly, and the company did not repurchase shares in the years 2009-2011.

As will be detailed in the next section, Novo Nordisk's share capital is divided into A shares and B shares, with its A shares providing majority voting rights to Novo Holdings, the holding company of the Novo Nordisk Foundation, a non-profit industrial foundation. Novo Holdings also holds B shares in Novo Nordisk, and 14.1\% of Novo Nordisk's B share repurchases in the period 2009-2018 were from Novo Holdings. A further 28.1\% of Novo Nordisk's total cash dividends were distributed to Novo Holdings, meaning that $20.7 \%$ of Novo Nordisk's total shareholder payout between 2009-2018 was distributed to Novo Holdings. Both share repurchases and cash dividends in total and excluding distributions to Novo Holdings are included in the graph below. At Novo Nordisk, during the first half of the decade, both total share repurchases and total cash 
dividend payouts grew steadily, and until 2016, the amount the company distributed in share repurchases was higher than the amount it distributed in cash dividends.

Figure 3.2. Distributions of share repurchases and cash dividends at Eli Lilly, Novo Nordisk and Sanofi, 2009-2018, USD\$ millions
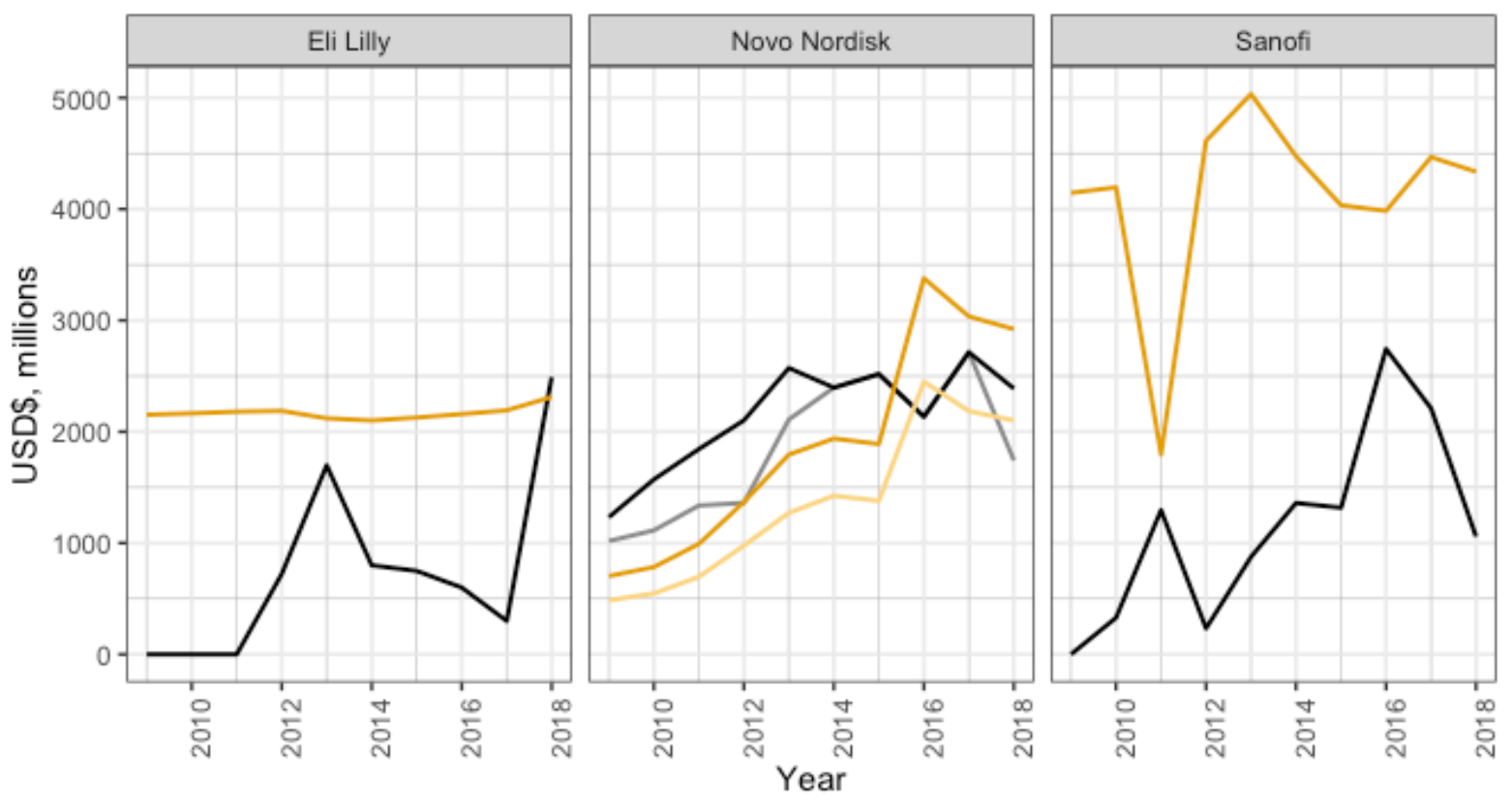

- BB (excl internal) — BB (total) - DV (excl internal) - DV (total)

$B B=$ share buybacks/repurchases; $D V=$ cash dividends

Data source: Bureau van Dijk/Moody's

It is clear that Eli Lilly spends a much higher percentage of revenues on R\&D than Novo Nordisk and Sanofi. Furthermore, its share buybacks are relatively low as a proportion of net income. The data suggest that Novo Nordisk is the most financialized of the three companies, with low spending on $R \& D$ as a proportion of revenue, and high spending on share buybacks as a proportion of net income. As already noted, the company is worth examining in detail, not only because of its industrial foundation model of corporate governance and relatively high total shareholder payout as a proportion of net income, but also because sales from insulin constituted $66 \%$ of its total net revenue between 2009 and 2018, and so the company's profits are particularly sensitive to changes in the list price of insulin. Eli Lilly and Sanofi do not have industrial foundation majority control. The Lilly Endowment, a private philanthropic foundation, is a principal shareholder of Eli Lilly, holding $11 \%$ of common stock, which funds its distributions to religious, community development and education causes (Eli Lilly, 2019; Lilly Endowment Inc., 2020). Unlike the Novo Nordisk Foundation, it is independent of Eli Lilly; it does not hold controlling stock and maintains a separate board of directors and trustees. 


\section{A closer look at Novo Nordisk}

In 2009, the amount that Novo Nordisk spent on R\&D was equal to $94 \%$ of what it distributed to external (private and institutional) shareholders in the form of cash dividends and share repurchases. In 2016 , that percentage had decreased to $42 \%$, a figure that only increased to $54 \%$ by 2018 . The importance of insulin sales to Novo Nordisk sits in contrast to Eli Lilly and Sanofi which, with far more diverse product lines, relied on insulin sales for just $16 \%$ and $18 \%$ of their total revenue respectively during this same period. Novo Nordisk's focus on insulin products has long been a deliberate company strategy; in 2011, then-Chief Executive Lars Rebien Sørensen told a reporter that rather than continue investing in research to develop pills for diabetes management, he had decided four years previously to "shut down Novo's pill research", opting to spend that money instead on insulin and other injectable diabetes medications, expecting that sales from this area would grow: "It was a calculated risk", he said (Langreth, 2011). This approach was echoed in the 2018 annual report, where company Chair Helge Lund outlined the Board's decision to "redefine[] the company's approach to research and development, reprioritiz[ing] resources towards key growth drivers and continu[ing] to streamline and simplify across the organization" (Novo Nordisk, 2019b, p. 1).

The strategic focus of resources on producing insulin has proved profitable. Gradually, the company's share of the global modern and new-generation insulin market has grown; today it is the world leader, holding a 45\% share in the \$26 billion global market. Sanofi and Eli Lilly hold $32 \%$ and $21 \%$ respectively (Novo Nordisk, 2019c, p. 54). Furthermore, the growth rate of the company's sales to North America has far exceeded that of sales to the rest of the world (see Figure 3.3). Today, North America absorbs $51 \%$ of the company's insulin sales, with total diabetes products accounting for $81 \%$ of Novo Nordisk's total revenues. Sales in the US market account for 97\% of Novo Nordisk's total North America insulin sales and 96\% of its total North America sales (Novo Nordisk, 2019b, p. 69).

Figure 3.3. Novo Nordisk sales to North America versus rest of the world, 1999-2018

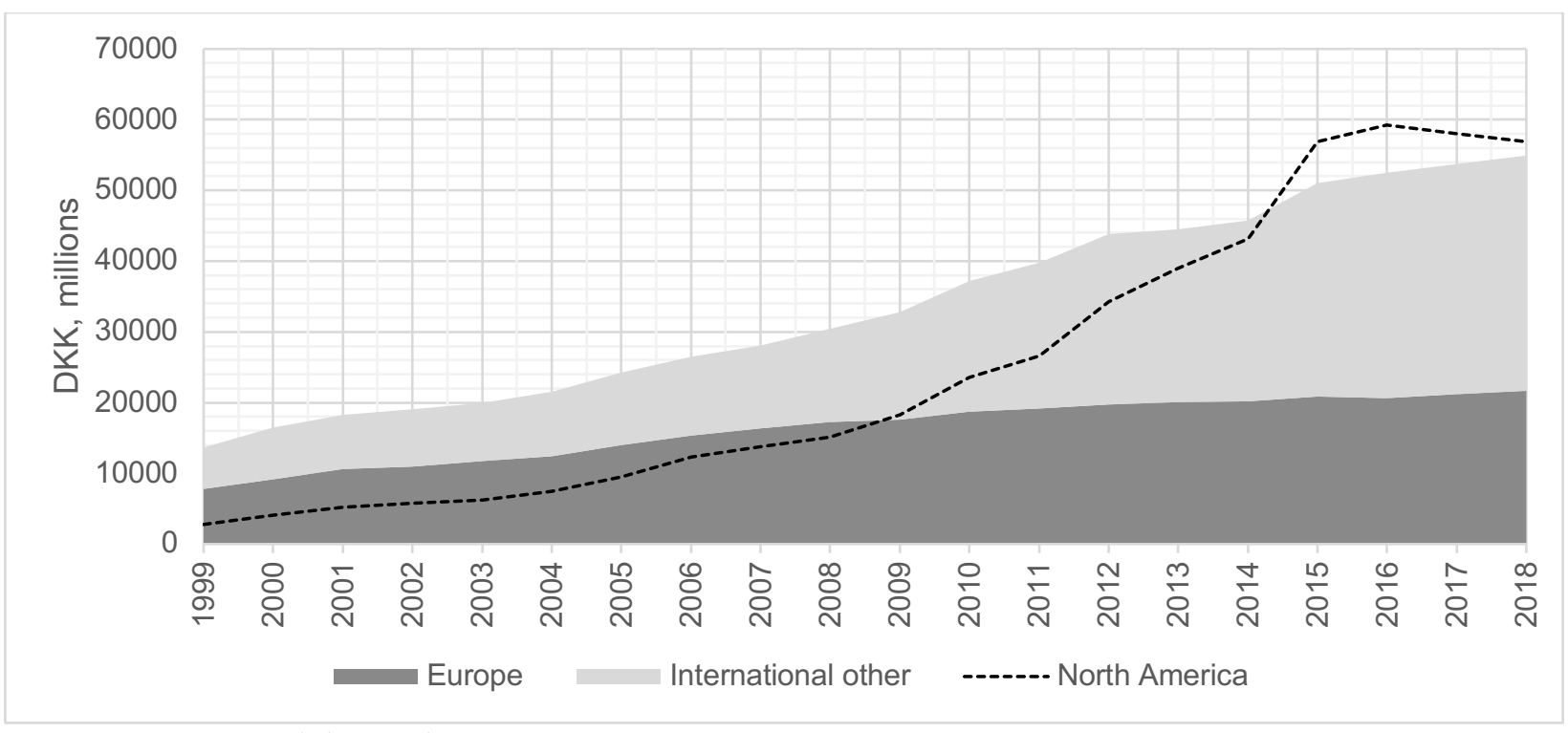

Data source: Novo Nordisk Annual Reports, 1999-2018 
Thus, the company's insulin revenue growth could be explained in part by the company's North America insulin market share growth over time. But, as Hernandez, San-Juan-Rodriguez and Good (2020) make clear, the net price of insulin medicines in the United States has increased, and, as a result, so has Novo Nordisk's net revenue from insulin products. During this same period, the amount distributed to shareholders in the form of cash dividends and share repurchases has soared. Crucially, the rate of TSP growth has far exceeded the growth rate of R\&D expenditure. This is shown in Figure 3.4. below.

Figure 3.4. R\&D spending versus total shareholder payout at Novo Nordisk, 1999-2018

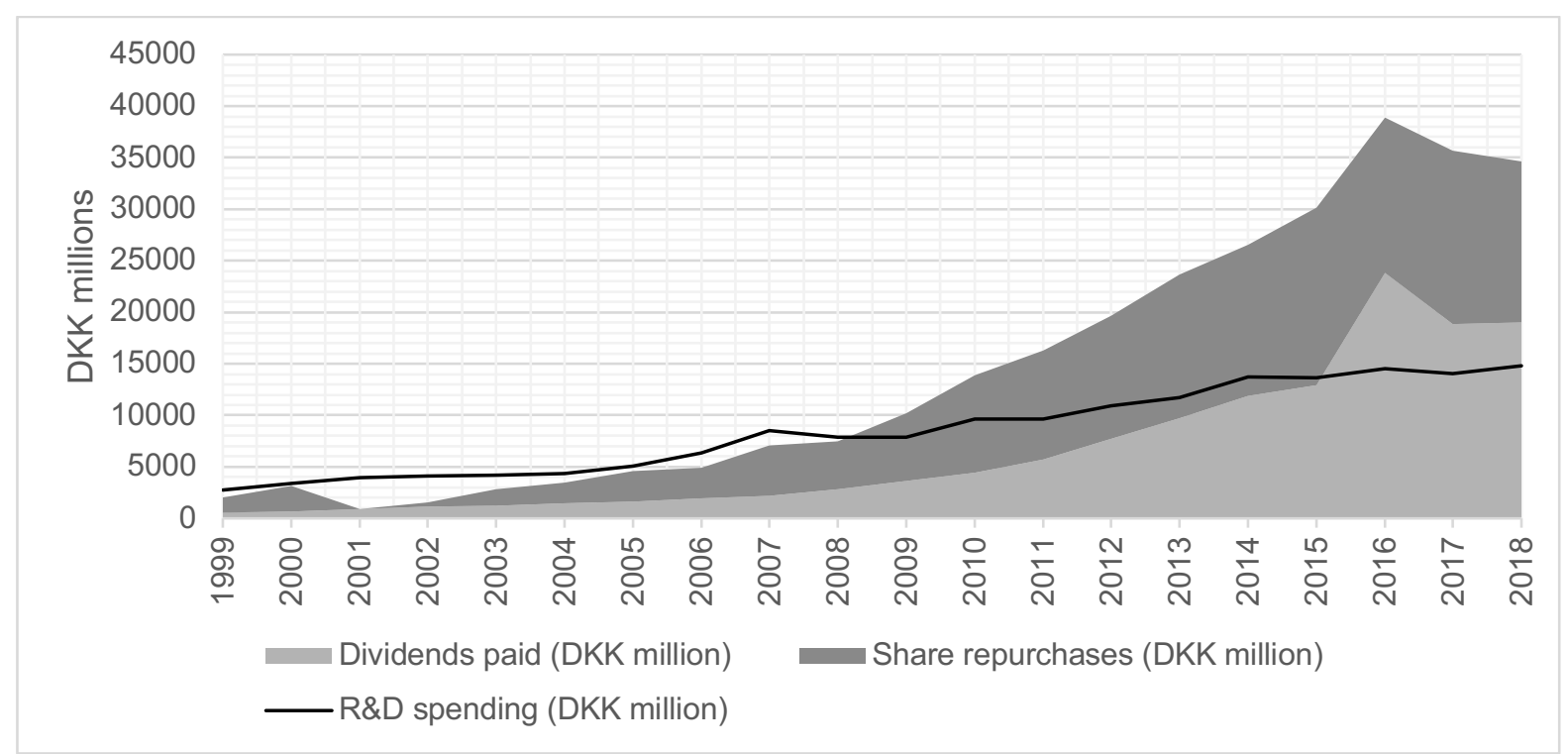

Data source: Novo Nordisk Annual Reports, 1999-2018

As is clear, Novo Nordisk has undertaken large share repurchases throughout this period. Tulum, Lazonick and colleagues have shown that the vast majority of share repurchases by US companies, including pharmaceutical companies, are done as open-market repurchases with the primary aim of manipulating the company's stock price (Lazonick, 2014; Lazonick et al., 2019; Tulum, 2018). The manipulation of company stock price for the benefit of the private and institutional investors that hold the majority of Novo Nordisk's B shares may also underpin Novo Nordisk's share repurchases. Figure 3.5. below indicates that the value of Novo Nordisk stock has indeed increased significantly, and particularly in the past decade when its share repurchases have been largest. Between January 1999 and December 2018, the value of Novo Nordisk shares increased by $2293 \%$. 
Figure 3.5. Novo Nordisk share adjusted close price, 1999-2018

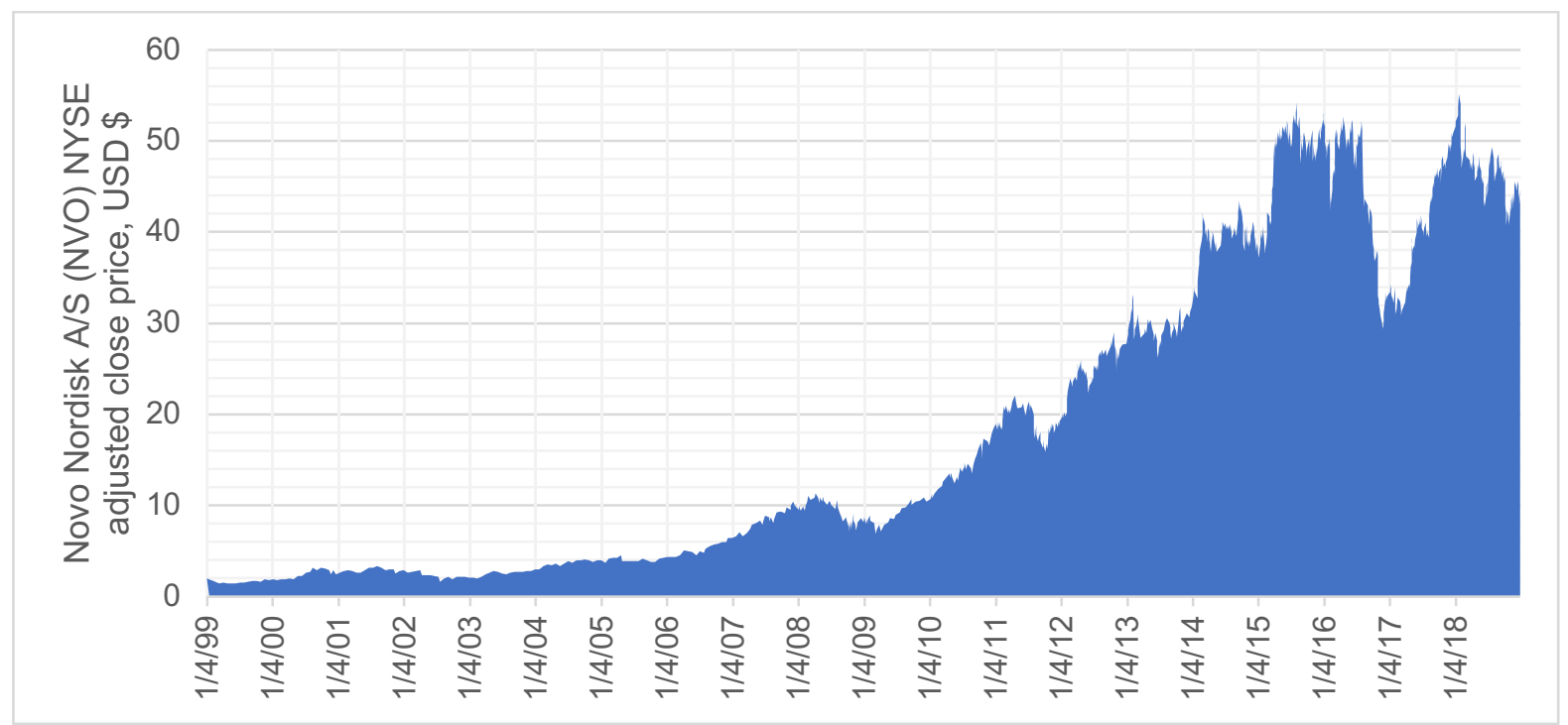

Data source: Yahoo Finance

However, to focus on the motivations behind share repurchases at United States-based companies might blind us to wider objectives that are perhaps unique to the industrial foundation model of the Novo Group. Novo Nordisk's total share capital is divided into A shares, which carry 200 votes each, and B shares, which carry 20 votes each. The majority of Novo Nordisk's B shares are held by institutional and private shareholders, constituting $23.9 \%$ of votes and $71.9 \%$ of capital at the time of publication of the company's 2019 Annual Report (Novo Nordisk, 2020). Its A shares are not publicly listed and are held by Novo Holdings, a Danish private limited company. Novo Holdings is wholly owned by the Novo Nordisk Foundation, a non-profit institution which, in addition to managing the commercial activities of the Novo Group of companies (Novo Holdings A/S, Novo Nordisk A/S and Novozymes A/S), also distributes some funding directly for scientific research and health programs, largely in the form of academic grants. These grants are often an important source of funding for universities and other public research institutions in Denmark and beyond; indeed, the scale and stipulations of the Foundation's and wider industry-related funding in Danish public research institutions has come under scrutiny from both politicians and academic staff in recent years (Broberg and Dohm, 2019; Novo Nordisk Fonden, 2019; Obitsø, 2018). Nonetheless, it is worth noting that relative to other distributions in the Novo Group, the amount distributed through the Novo Nordisk Foundation grants is relatively small; the DKK1.7 billion spent on grants in 2018 was equal to just $7 \%$ of the total amount that Novo Nordisk distributed to external (private and institutional) shareholders in in the same year. ${ }^{2}$

\footnotetext{
${ }^{2}$ Grants awarded = DKK1.749 billion, total distributed to external (private and institutional) shareholders in share repurchases and dividends $=$ DKK25.055 billion
} 


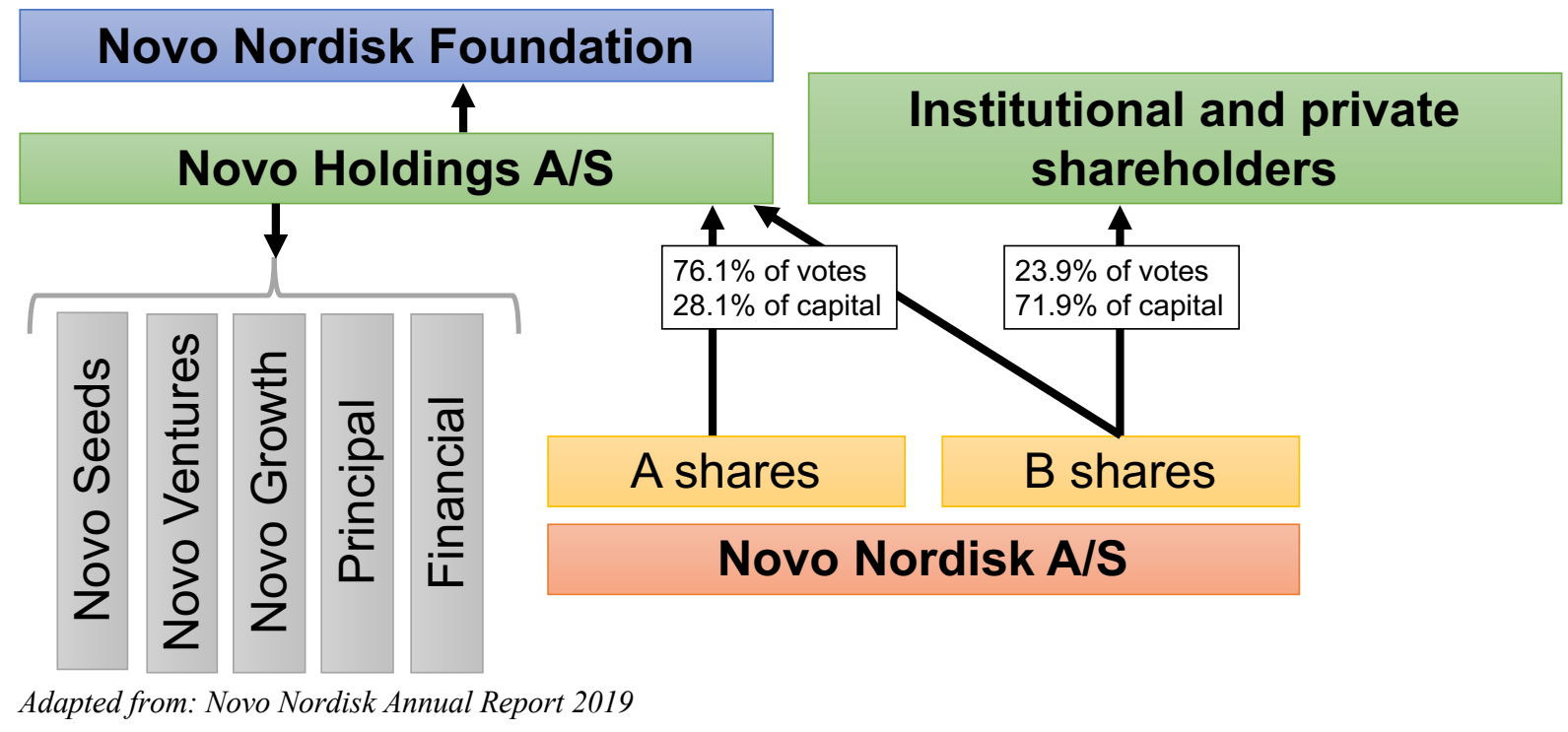

Novo Holdings is the Novo Nordisk Foundation subsidiary responsible for managing the Foundation's wealth, which includes the value extracted through its A shares in Novo Nordisk A/S. At the end of the 2019 financial year, Novo Holdings also held a B share capital of nominally DKK27.15 million (Novo Nordisk, 2020). Novo Holdings's shares in Novo Nordisk endow it with $76.1 \%$ of votes at annual meetings and $28.1 \%$ of capital (ibid.). Novo Holdings invests in companies through four programs: Novo Seeds, which provides capital to life science start-ups; Novo Ventures, which provides venture capital to both private and publicly-traded companies; Novo Growth, which invests in life science companies it deems 'scalable' through equity; and its Principal Investments program, which focuses investments in established life science companies. It also invests in equities, bonds, credits and alternatives outside of the life science industry (Novo Holdings, 2020). The company's total financial investments for the period 2015-2018 totaled DKK162.8 billion, and its investments in what can broadly be considered R\&D through capital investments in start-ups, SME biotech companies and established companies through the various programs constituting its "Life Science Investments" totaled DKK183.6 billion. An overview of these figures is provided in Figure 3.7. 
Figure 3.7. Novo Holdings investments, 2015-2018

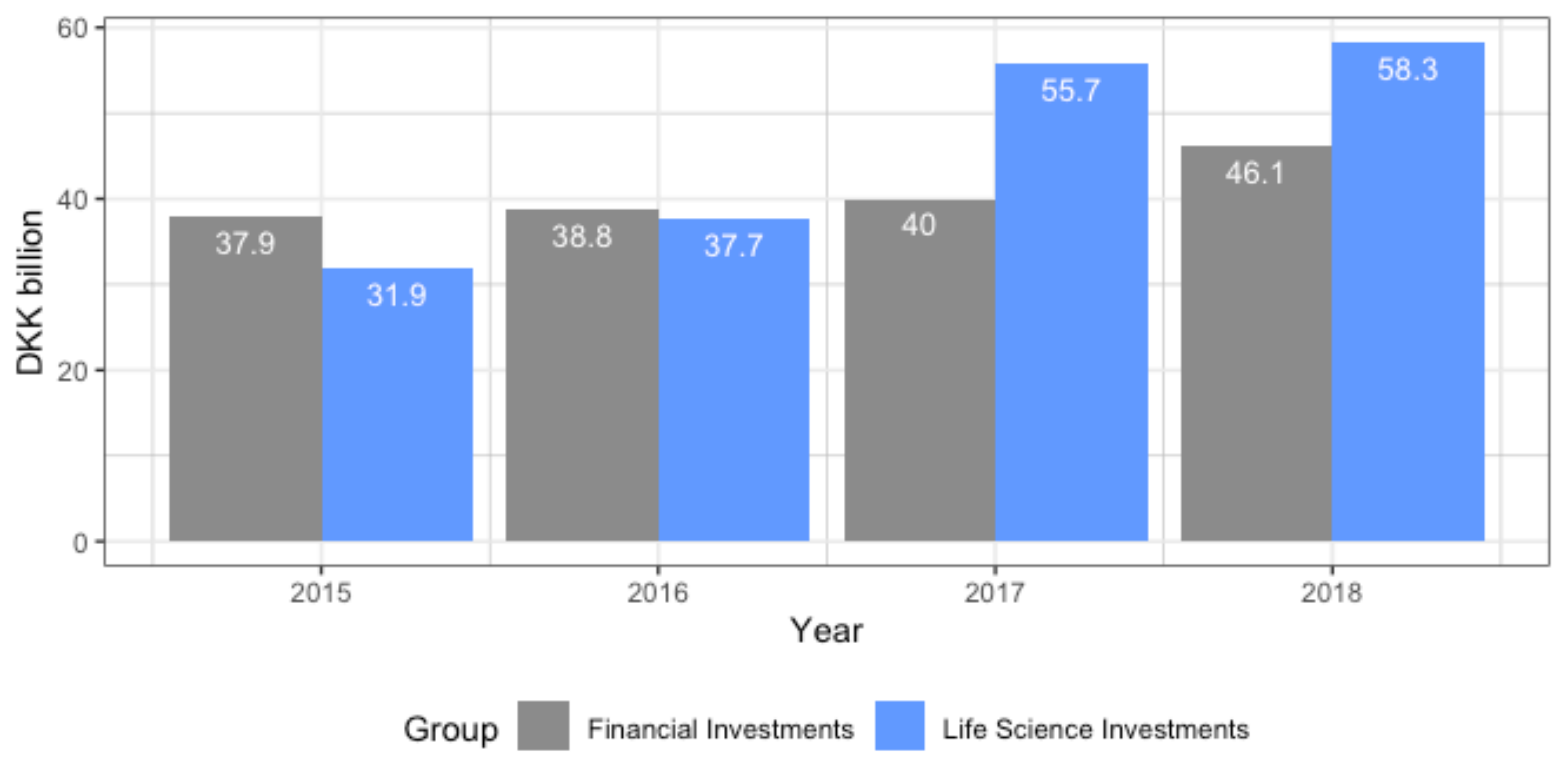

Data source: Novo Holdings A/S and Novo A/S annual reports, 2015-2019

Many of the companies Novo Holdings invests in do not currently produce a product. There are two primary reasons why such companies are able to raise funds from established actors in the pharmaceutical industry. Firstly, in the case of publicly listed companies without a product - or "PLIPOs" (Lazonick et al., 2017b, p. 13) - they are regarded as speculative assets, bought and sold on the basis of "news" such as that generated by clinical trials, without concern about whether a commercial drug is ever actually produced (ibid.; Roy and King, 2016). Secondly, they can be considered sources of research and development. Small biotech companies and start-ups can and do develop new medical technologies and treatments, but this funding model can be "disruptive of the collective and cumulative learning that is needed for successful drug development" (Lazonick et al., 2017b, p. 13), as it depends on the tumult of the speculative stock market. It is likely that often the specialized knowledge generated by different companies in an investment portfolio develops in silos, owing to company incentives to protect research findings and product developments under the existing intellectual property infrastructure. Future research might explore this hypothesis, considering to what extent and how the uncertain, collective, and cumulative character of successful innovation processes is managed through organizational integration of the portfolio companies, the (time) commitment and scope of the financing, and the relationship between such resource allocation decisions and the investing company's existing capabilities - i.e. its strategy (Lazonick, 2017, pp. 14-19). In so doing, it will ask how distributing profits to smaller biotech companies relates to innovative capabilities and distributions to workers as stakeholders in the development of innovations.

As noted, Lazonick, Tulum and colleagues have argued that there is a tension between innovation and financialization within pharmaceutical companies that engage in large share repurchases, as share repurchasing undermines strategic control, organizational integration (mobilization of the skills and efforts of employees to engage in organizational learning), and the availability of longterm finance necessary for investment in the development of safe, affordable and improved drugs 
(Lazonick et al., 2019, 2017a; Tulum, 2018). The data above suggests that at Novo Nordisk, this particular tension is tempered to an extent through the industrial foundation model of corporate governance, as access to some long-term finance is guaranteed through the holding company investments. Furthermore, control over strategic decisions is maintained by the Novo Nordisk Foundation through Novo Holding's A shares, although decision-making is influenced by the interests of B shareholders, which account for $71.9 \%$ of total share capital. Nonetheless, a tension between innovation and financialization can be said to exist at a level beyond the firm and its national institutions, where Novo Nordisk's stability in recent years has been contingent on increasing the costs of insulin for by type-1 diabetes patients in the United States - itself a form of value extraction.

In summary, the above discussion has shown that, at Novo Nordisk, the amount distributed to shareholders during this period was more than double the amount spent on R\&D. This imbalance is of particular interest because of the relative importance of insulin products to the company's net revenue compared to the other companies. $66 \%$ of Novo Nordisk's net revenue between 2009 and 2018 came from sales from insulin products, and today, 49\% of the company's insulin sales are absorbed by the United States. Over the decade 2009-2018, the growth rate of the company's sales to North America far exceeded that of its sales to the rest of the world. That growth, these data suggest, is largely the result of insulin list price increases.

Recognizing that $76.1 \%$ of Novo Nordisk's voting rights come through shares held by a holding company wholly owned by the Novo Nordisk Foundation, this paper has interrogated how a strategic focus on share-value growth through the large share repurchase programs of the last decade might have supported or undermined innovation processes within the Novo Group. Novo Holdings distributes finance to a number of companies, from product-less start-ups to larger biotechs. The analysis suggests that while this corporate governance model may provide the Novo Group with relative stability through the provision of access to long-term finance, that capital investment has in recent years relied on the rising profits resulting from higher insulin list prices, pointing to a tension between innovation and financialization that exists beyond the firm and Danish institutions. Higher insulin prices have provided a source of long-term finance necessary for future innovation, but this may have adversely affected type-1 diabetes patients' access to treatment in the United States (Herkert et al., 2019; T1International, 2019). Further research is needed to evaluate the objectives of Novo Nordisk's particular share repurchasing programs, building on the preliminary data above, and considering, for example, whether changes in the structure of executive remuneration may also have influenced executive decision making (Hopkins and Lazonick, 2016).

This section has provided an overview of how the three insulin-manufacturing companies distribute profits. Although it is indisputable that R\&D costs have increased in recent decades, the companies' financial data suggest that list price increases have not been solely or principally driven by research and development objectives. Consistent with earlier research on the wider US pharmaceutical industry, the paper has presented data suggesting that share repurchases have played an important role in the financing and corporate governance of Eli Lilly, Novo Nordisk and Sanofi, though the extent and nature of financialization varies across the three companies and over the period 2009-2018. During this period, the total amount distributed to shareholders by the three companies was $\$ 122$ billion, and there are important differences in what this means in practice at 
each of them. Eli Lilly, for example, spends a much higher percentage of revenues on R\&D than Novo Nordisk and Sanofi. Its share buybacks are relatively low as a proportion of net income, and distributions to shareholders through cash dividends are far higher than share repurchases. In such a financialized market, the motivation to "maximize shareholder value" must nonetheless be considered as a driver of list pricing decisions, though further research is needed to explore the how this plays out in each of the three insulin manufacturing companies and influences pricing decisions. Fundamentally, if a funding model to develop new medical technologies requires higher list prices that reduce patients' access to existing treatments, we must investigate whether it is really worth pursuing or even constitutes 'innovation' at all.

\section{Which other actors in the insulin supply chain benefit from list price increases?}

While shareholders and company executives of drug manufacturers are the only actors within the insulin industry with an interest in increasing stock prices, understanding the various relationships involved in the supply chain enables us to identify which other actors may benefit from and seek to influence insulin list price increases, and how they contribute to, or undermine, pharmaceutical innovation processes.

Figure 4.1. The pharmaceuticals supply chain in the United States

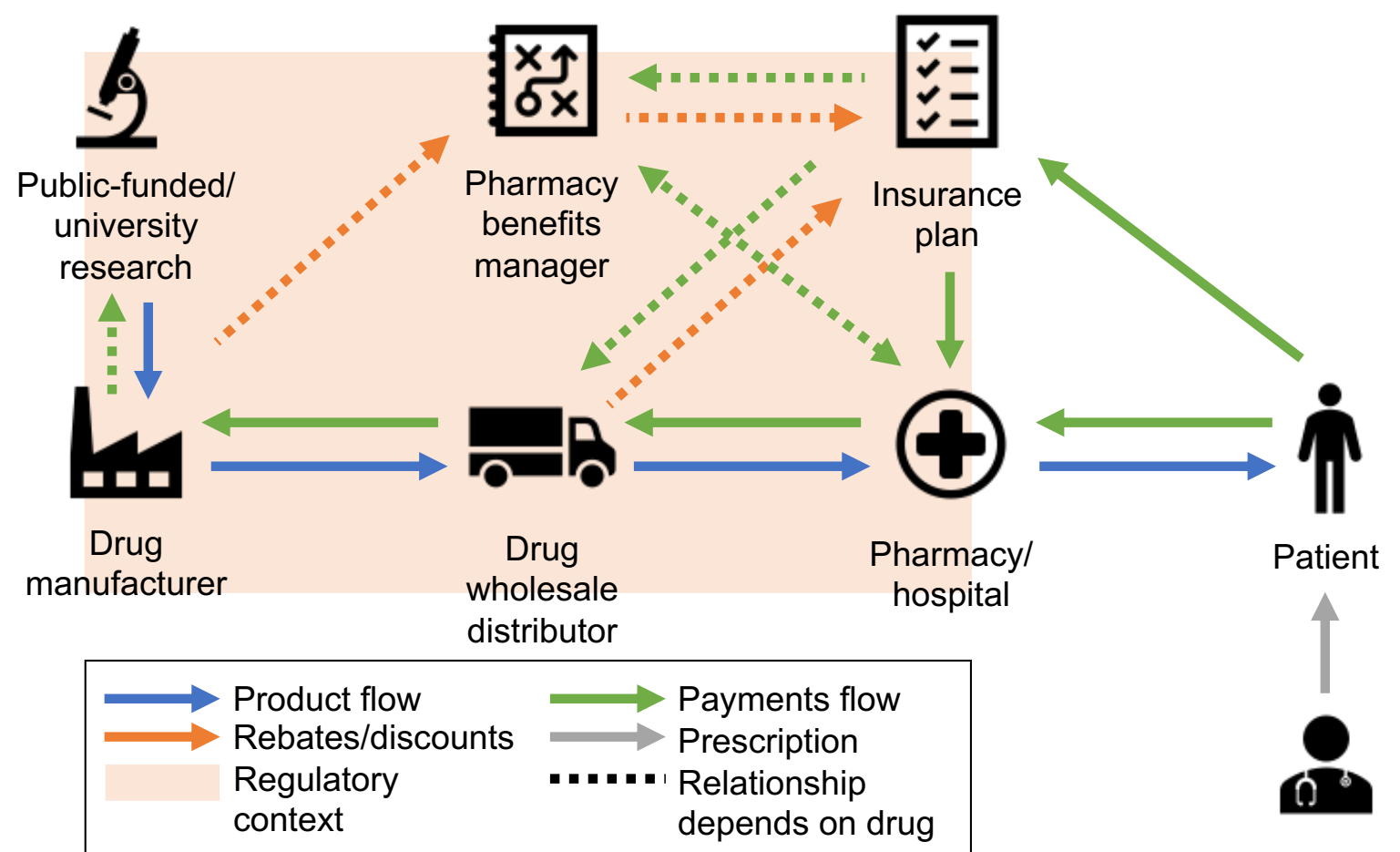

Physician

\section{The beginning: the role of the government sector in the development of insulin}

It is often taken for granted that the development of a drug begins in a pharmaceutical company; this myth is propagated by the pharmaceutical industry and its interest groups. For the majority of medicines on the market today, however, it is far from the truth. Throughout the twentieth century, 
governments around the world, particularly in North America and Europe, provided significant public funding for basic science and medical research at universities and other public institutions (Goodman, 2003, p. 146; Lazonick and Tulum, 2011; Malerba and Orsenigo, 2015, p. 669; Mazzucato, 2018, pp. 75-77). From 1938 through 2018, the US National Institutes of Health (NIH) spent over \$1.1 trillion on publicly funded life-sciences research, with a budget for 2019 of \$39.3 billion (Lazonick et al. 2019). Researchers at Bentley University in Massachusetts identified that every one of the 210 new drugs approved by the Food and Drug Administration in the United States between 2010 and 2016 had received funding from the NIH at some stage in their development, worth in total more than $\$ 100$ billion (Cleary et al., 2018; 2020).

Today's insulin formations owe their development in no small part to government-funded research institutions and research projects in the twentieth century. Michael Bliss has detailed the cumulative learning across laboratories in North America and Europe that led to the first use of insulin in diabetes treatment developed by Banting, Best, Collip and Macleod in 1922 (Bliss, 2019). These academic scientists were affiliated with the University of Toronto and decided to grant Eli Lilly a one-year license to produce and develop the medicine; once they realized that insulin was saving the lives of patients, it became imperative to have a regular supply to keep patients alive, which Lilly was positioned to deliver. Although the agreement permitted Eli Lilly to apply for patents on improvements it made in the manufacturing process within the United States, the company promised to deliver the medicine with minimal profit.

Insulin continued to benefit from government-funded research and learning within governmentsector institutions throughout the twentieth and twenty-first centuries. Human insulin, for example, was developed building on research funded by the NIH and the American Cancer Society (Hughes, 2011). Throughout the early 1970s, Herbert Boyer, a UCSF-based scientist, and Stanley Cohen from Stanford University worked to develop recombinant DNA (rDNA). By 1978, Boyer and his colleagues at Genentech, which he founded with Robert Swanson as a vehicle for accessing venture capital to continue researching rDNA, had produced the world's first human insulin (Hughes, 2011, pp. 75-98; Owen and Hopkins, 2016, p. 16).

This role of government-sector funding and institutions in the supply of insulin today should not be overlooked, even if it remains largely unaccounted for in both financial reports and in narratives of technological innovation. To some extent, this lack of recognition can be blamed on the inherent challenges of calculating the value of early stage R\&D, particularly when most basic research for example, exploring cellular or molecular processes - does not produce useful findings. It has been suggested that up to 10,000 compounds may be considered in the search for a new treatment, with just one ultimately developed into a new medicine (Torjesen, 2015).

Because scientists cannot know in advance which compounds will contribute in the end to a medical breakthrough, the wider research - including projects which do not produce hypothesized results - is crucial and must be funded (Lazonick and Mazzucato, 2013, p. 1098). The medical innovation process is intrinsically uncertain, because the majority of funded early stage research projects do not produce immediately utilizable results. For many medicines, it has been the government sector that has borne the risk of funding this (often expensive) early-stage research, with the business sector developing it at a less-risky stage - i.e. when findings indicate that a compound or group of compounds may have a desired effect on patient populations (Cleary et al., 
2018; 2020; Hopkins and Lazonick, 2015; Lazonick and Tulum, 2011; Mazzucato, 2018). Despite bearing the risk of the investment needed to develop new medicines, however, the government sector rarely receives compensation proportional to its investment from the eventual sale of medicines. In some cases, the university or national laboratory recovers costs, for example by transferring federally-funded research to commercial entities as per the Bayh-Dole Act of 1980 (Jaffe et al., 1998; Link et al., 2011; Mowery et al., 2004; Siegel et al., 2007; Thursby and Thursby, 2011).

The United States is a notable example of the many countries that not only provide extensive funding for the basic research that underpins development of new, profitable and patentable medicines, but also wider infrastructure that the companies rely on for product markets - from transport links involved in supply chains to university education for future employees. In Denmark, where Novo Nordisk is headquartered, for example, education has long been considered a public good, and there are no tuition fees to study at university. This government subsidy has provided the company with a large, highly talented pool of potential employees, educated at the expense of the taxpayer.

Scant literature exists on the proportionality of pharmaceutical companies' taxation or the potential for taxation to act as a means of (re)distribution of pharmaceutical industry profits to the government sector, though a report by the charity Oxfam in 2018 suggested that four of the world's biggest pharmaceutical companies - Pfizer, Johnson \& Johnson, Abbott, and Merck \& Co - had underpaid \$2.3 billion in taxes in the United States between 2013 and 2015 (Fried, 2018, p. 30). In the insulin industry, between 2009 and 2018, Eli Lilly paid an effective tax rate of 19\%, Sanofi $21 \%$, and Novo Nordisk $22 \%$. To put this into context, at all three companies, the amount paid in taxation over the ten-year period was less than a third of the total distributed to shareholders in the form of cash dividends and share repurchases.

Further complicating the relationship between government- and business-sector $R \& D$, the majority of start-ups that come to be listed on the stock market (predominantly NASDAQ in the United States) begin their life as spinouts of government-funded research projects conducted in university and public research institutions. These start-ups often do not have a product when they are initially listed, but an established drug manufacturer might nonetheless seek to acquire the company at a very high price to gain access to a drug in development, knowing that, if it is approved, it will be able to recoup the purchase price of the acquired company by setting a high list price for the drug. The possibility for a start-up to be listed on NASDAQ even without a commercial drug increases its leverage in securing a high purchase price, especially if there is a bidding war among drug manufacturers. In this way, the commercialization of government-funded research through the establishment of a spin-out by university researchers may also factor into higher list prices.

\section{Other actors in the insulin supply chain}

As noted already, it is the drug manufacturer that holds the patent or a license from the patent holder to produce and sell the drug, and that formally sets the list price for the drug. It does this in negotiation with other actors, the relationships between which are described in Figure 4.1. The ways in which profits are distributed to the various actors in the insulin supply chain are necessary 
for understanding potential factors driving up product list prices - and thus likely hindering patient access.

The structure of the pharmaceutical supply chain also provides the foundation for evaluating whether the profits distributed to and extracted by these actors are used in ways that contribute to value creation processes. In addition to the manufacturer's internal strategy, the power of other actors in the supply chain of a medicine can influence list price setting. Other sectors involved in the distribution, administration and dispensation of prescription medicines profit through negotiating discounts to purchases of treatments and securing rebates following the sale of a drug. The American Diabetes Association's Access and Affordability Working Group has argued that it is the intermediaries in the pharmaceutical supply chain that benefit most from the price increases of insulin. According to the group, "as list prices increase, the profits of the intermediaries in the insulin supply chain (wholesalers, PBMs, pharmacies) increase since each may receive a rebate, discount or fee calculated as a percentage of the list price" (Cefalu et al., 2018a, p. 11).

Once a product receives market authorization, wholesale distributors (and sometimes other direct purchasers) purchase the drug at the list price (in this context referred to as the wholesale acquisition cost or WAC). This is the baseline price at which wholesale distributors (and sometimes other direct purchasers) purchase the drug, before discounts and rebates are applied based on market share, volume and prompt payment (Kaiser Family Foundation, 2005, p. 17). They then store the medicines in warehouses and distribution centers across the country, from where they are delivered to pharmacies and hospitals. They thus play a key role in supply-chain logistics. The amount which wholesale distributors receive for providing these logistics services is calculated as a percentage of the list price of the medicines they handle rather than the actual resources needed to distribute and store specific products. Thus, wholesale distributors stand to benefit from higher drug list prices (Cefalu et al., 2018a, p. 7), particularly for medicines with high demand like insulin formulations.

Pharmacies and hospitals, which purchase drugs from wholesale distributors, dispense medicines to a patient once a prescription provided by a physician has been submitted. The dispensary will then submit a bill to the individual's insurance plan, if they have one, and receive reimbursement for the prescription, plus fees for dispensing (Cefalu et al., 2018a, p. 2). They may also collect a co-payment from the patient or, if a patient does not have health insurance that covers the prescription, the pharmacy will usually charge a price close to its purchase price, with a markup (ibid.).

These actors - the manufacturer, wholesale distributor, pharmacy and patient - represent the product flow of the insulin supply chain, from production to storage, distribution, and dispensation. Beyond this chain, however, two further actors receive a share of the list price amount. These are pharmacy benefit managers (PBMs) and insurance plans.

The United States does not have a uniform healthcare system, but in general, individuals are expected to take out health insurance through either private or public health insurance plans to cover their healthcare costs. As noted, however, many individuals are not covered by any form of health insurance, and therefore must pay for prescription medicines and other health services outof-pocket. Insurance plans receive payment from individuals or their employers for coverage, or 
they are provided by the government. In theory, insurance plans enable individuals to manage the uncertainty inherent in future health needs (and costs) by 'pooling' risk. In theory, it is in the interest of insurance plans to seek lower list prices of medicines, where they cover the costs for patients. Historically, insurers' quest for lower list prices has also been true in practice. As the list prices of many medicines have increased, however, insurance companies may have shifted the higher costs onto patients in the form of higher co-pays and premiums (Kaiser Family Foundation, 2019, pp. 156-158). Insurance plans often also receive rebates from drug manufacturers after the point of sale, incentivizing coverage of particular medicines and not others.

In the past, insurance plans were able to influence the list price of pharmaceutical products by way of PBMs. The first PBMs were established in the 1960s, with backing from private insurance companies, which were increasingly tasked with managing small claims as business-sector prescription drug coverage grew (Strongin, 1999, pp. 2-3). With the introduction of the plastic drug benefit identification card in the 1970s, PBMs served as important administrative intermediaries between pharmacists, insurance plans, and patients, fostering networks of pharmacies, as well as mail-order services that enabled patients to receive their prescription medicines in the mail (ibid.). In the 1980s, the role of PBMs in the pharmaceuticals supply chain evolved again, as pharmaceutical companies began sharply increasing the list prices of many prescription medicines. PBMs assumed the role of fiscal intermediaries, using their relationships with insurers and the networks of pharmacies they had built to negotiate rebates with manufacturers based on the amount of their firm's products dispensed by the PBMs' participating pharmacies. They leveraged their unique position as well to negotiate volume-pricing discounts with pharmacies, and created formularies, which are lists of preferred pharmaceutical products, incentivizing manufacturers to offer discounts to the PBMs on medicines they want to be covered by insurers. This period, it can be said, marked the birth of the PBM as it exists today.

The relationship that has developed between PBMs and pharmacies is perhaps the most important for understanding why PBMs stand to benefit from higher list prices, rather than appease insurance plans by negotiating for upfront discounts with manufacturers. The fees charged to pharmacies by PBMs are based on list prices; PBMs thus have an interest in maintaining a high list price but negotiating retrospective rebates with the manufacturer, which they receive after the dispensation of the drug (Wapner, 2017). In most cases, these higher fees ultimately fall on individuals rather than insurance plans, as they increase co-pays and premiums to cover the higher prices charged to pharmacies. PBMs have faced bipartisan criticism for this arrangement; in 2019, senators questioned the legitimacy of the power wielded by the three companies that dominate the market and challenged the profits they make through high rebates (Kuchler, 2019). It is doubtful that PBMs improve patient access through lowering drug prices or contributing to pharmaceutical innovation processes today, but it is indisputable that they stand to benefit from higher insulin list prices, and thus should be understood as an actor that has contributed to this situation. Unlike manufacturers, neither PBMs nor insurance companies contribute to medical innovation or can claim to create value.

The concentration of this activity and others in the pharmaceuticals supply chain is often cited as an important factor in the list price increase of many drugs in the United States, and the consequences for reduced patient access (Sood et al., 2017). CVS Caremark, Express Scripts and Optum Rx today manage about $70 \%$ of all prescription claims (Cefalu et al., 2018a). Three 
wholesalers similarly control $85 \%$ of the market; five pharmacies hold $54 \%$ of their respective sector; and the market for insurers is increasingly concentrated (Sood et al., 2017). But ultimately, the ability to drive up the prices paid by patients at all, in such a way that not only inhibits access, but fosters the extraction of value by shareholders and other actors in the supply chain that do not contribute to medical innovation processes, is only possible because of the regulatory context discussed at the beginning of this paper. No one argues that a hypothetical state-owned insulin manufacturer would need 'competitors' to keep its products affordable; compulsory licensing and other publicly accountable regulatory-legal tools are instead invoked as possibilities for ensuring access for all. Insulin prices are high - and this benefits financial interests that extract far more value than they help to create - because that is what the political infrastructure allows.

This section has described the functions of actors in the pharmaceuticals supply chain as they relate to the list pricing of insulin, patient access, and medical innovation processes in the United States. The insulin supply chain at present is complicated, and a range of industrial sectors beyond the manufacturer stand to benefit when list prices increase. At every stage of the supply chain, the potential profits available to intermediaries are influenced by the list price set by the manufacturer, and the option to use retrospective rebates in negotiations between actors further harnesses interests in maintaining higher list prices. Wholesale distributors and pharmacies can be considered important as logistical intermediaries in the insulin supply chain, though the possibility of value extraction through them by processes of financialization warrants further research. The same cannot, however, be said for PBMs. This actor has mutated throughout its existence, creating new relationships within the supply chain and adopting new functions ever since its establishment in a period of increased prescription coverage and drug access. Today, it is not clear how this activity contributes to either patient access or medical innovation processes, and it could therefore be considered primarily an extractor of value from patients, government-funded research and other actors involved in drug development and delivery.

\section{Conclusions and directions for further research}

This paper has provided an overview of the political economy of analogue insulin access in the current US healthcare system. It has described how the list prices of insulin formulations have changed in recent years, what implications list price increases have for patient access in the context of the pharmaceuticals supply chain in the United States, which actors have benefitted most from list price increases, and the relationship of these actors to medical innovation processes.

In the first section, I showed that the three insulin manufacturers have benefitted from the insulin list price increases of the past decade. With the profitability of list price increases for manufacturers established, I examined how the manufacturers have distributed the higher profits from the sale of higher-priced insulin medicines. First, I considered whether R\&D investment had increased as profits from the sale of insulin had grown. The rate of increase in R\&D spending for the years 2009-2018 was far lower than the projected additional revenue from insulin described in the first section. The paper showed that, during this period, distributions to shareholders in the form of cash dividends and share repurchases soared. This echoes data produced by Lazonick, Tulum and colleagues on the wider US pharmaceutical industry (Lazonick et al., 2019), and suggests that the manufacturing companies' shareholders have been beneficiaries of list price increases. We should therefore consider that in list price setting the goal of "creating shareholder value" has functioned as an important force for predatory value extraction (Lazonick and Shin, 2020). 
The paper then considered Novo Nordisk in further detail, recognizing that its particular ownership structure, in which majority voting rights are held by a company owned wholly by a non-profit industrial foundation, merited further examination. It is clear that Novo Holdings distributes funds to companies that invest in medical $\mathrm{R} \& \mathrm{D}$, and that the industrial foundation model of corporate governance may provide relative stability through ensuring access to long-term finance. However, this structure has not undermined the extent to which the company has stood to benefit from the insulin list price increases of recent years. Indeed, Novo Group's long-term financial resources have been contingent on insulin price increases. Thus, a tension between innovation and financialization exists at a level beyond the firm and its national institutions, because Novo Nordisk's stability has been contingent on a form of value extraction from diabetes patients in the United States, who have been forced to pay higher prices for life-saving medicines. It may be that high insulin prices are actually funding medical research within the Novo Group, but in this case the decision about how to use the profits from high insulin prices in the United States are being made by a company based in Denmark.

The paper suggests that further research is needed to ascertain the contributions of the life science companies that Novo Holdings invests in to medical innovation and new technologies, particularly in the case of so-called PLIPOs. The development of knowledge through such an investment strategy can be fragmented due to the inconsistency of funding that is dependent on the speculative stock market. It may also become siloed, as developments take place within companies working separately that have incentives within the current intellectual property infrastructure to withhold research developments from other companies. The discovery of new medical treatments by contrast is the result of collective and cumulative learning, which is fostered when companies seek to retain and reinvest in their own capabilities and workers, à la the old economy business model of most pharmaceutical companies in the post-WWII decades (Lazonick, 2009).

In any case, the wider motivations of Novo Nordisk's share repurchases are worthy of further investigation. To what extent does executive remuneration at the company influence share repurchasing, or are such interests held in check through the industrial foundation model of corporate governance (Thomsen et al., 2018)? To what extent are medicine list price increases and share repurchases used as a means of value extraction for the sake of long-term or stable investment, in the face of an impending 'cliff edge', that looms as biosimilar or lower-priced analogue formulations are primed to take over the market? Could high medicine list prices indicate that a financialized firm is in crisis, after pursuing a strategy of prioritizing shareholder value over investment in the internal capabilities necessary to develop new, innovative, safe, effective, affordable and accessible medicines? What are the attributes of organizations that do generate safe, effective, affordable and accessible medicines?

After establishing how shareholders extract value from manufacturing companies, the paper considered the role that other actors play in the insulin supply chain and medical innovation processes. It is surprising how little research and data exist describing the relationship between value creation and value extraction of the actors that exist between the government-funded research underpinning new drug formulations, the manufacturers, and patients. The study of the role of PBMs in creating an imbalance between value creation and value extraction is worthwhile research priority: Quantitatively, how influential are they in the determination of list prices? What 
proportion of list prices are distributed to this activity? To what extent can financial interests and maximizing shareholder value be said to steer their influence on list price determinations, and what does this tell us about the relationship between value creation and value extraction within the United States medicines supply chain?

Initial research for this paper began in April 2019, shortly before the introduction of the first generic analogue insulin product. An earlier iteration hypothesized that the high list prices set by the three insulin manufacturers for their insulin products may be a manifestation of the financialized corporate governance model in crisis - a model that, to varying degrees, all three insulin manufacturers described in this paper had adopted. This model prioritizes meeting "shareholder expectations" for value extraction above investment in the productive capabilities necessary for innovation. Increasing list prices can be a symptom of such a model, summed up by pharmaceutical industry consultant Bernard Munos in 2016 as follows:

Most [drug companies] do not produce enough innovation to grow. In fact, half of them are shrinking. They try to mitigate this by escalating prices, which is dangerous. I think industry is misjudging the anger that its practices are creating. The risk of a backlash is real. (Bender, 2016, p. 59)

Depending on the actual contribution of the companies that Novo Holdings distributes finance to, such a situation may well be manifest in the case of Novo Nordisk. Increasing list prices to "maximize shareholder value" could only be regarded as predatory value extraction, because value extraction from the buyer through the price of insulin is not justified by value creation (i.e. the quality and accessibility of the product). Nonetheless, prices can only go so high, even in the United States with its conspicuous lack of price controls, and list price growth cannot last forever. Without a commitment to R\&D that matched the company's distributions to shareholders, how could value extraction be sustained? This is a paradox of the financialized corporation. Novo Nordisk relies on sales of insulin for more than $60 \%$ of its revenue, and without the ability to determine the list prices of insulin formulations in a health care system so unlike the one in the Scandinavian country where it is headquartered, where will profits come from in the future? The company saw some success following the launch of two new products for the treatment of type- 2 diabetes last year, but for growth rates to continue at the rate seen by the company during the years that list prices of insulin products were hiked will require similar list price increases for its type- 2 diabetes product range and/or higher prescribing rates of type- 2 diabetes and obesity medicines. The latter strategy relies on increased prevalence and diagnosis of type- 2 diabetes and obesity.

Clearly, our understanding of the tensions inherent in innovation and financialization would benefit from in-depth studies of the organizational integration, resource distributions and strategic decisions (Lazonick, 2017, pp. 14-19) of the three companies that make up the insulin industry. Future research might draw on other studies exploring this tension in other therapeutic areas and geographies (Lazonick et al., 2019; Roy and King, 2016; Tulum, 2018; Tulum and Lazonick, 2018).

The insulin industry warrants further research because its pricing decisions and the distribution of profits from higher list prices among shareholders, innovative capabilities and other actors along the pharmaceuticals supply chain not only matter for patients, but likely hold important lessons for 
other actors with an interest in medical innovation processes, as well as industries that have adopted corporate governance models that prioritize the interests of shareholders above all else. The analysis presented in this paper suggests that financialization could be considered the enemy of not only the development of new products that will be available to patients in the future, but also the affordability of products that are on the market now. This tension ultimately forces us to analyze the social conditions that enable innovation in the development and delivery of safe, effective and affordable drugs. 


\section{References}

American Diabetes Association, 2019. Statistics About Diabetes. Available from: https://www.diabetes.org/resources/statistics/statistics-about-diabetes. [Accessed 1.26.20].

Bender, E., 2016. Change big pharma. Nature. 533, p.59. Available from: https://doiorg.ep.fjernadgang.kb.dk/10.1038/533S59a. [Accessed 1 December 2019].

Bliss, M., 2019. The Discovery of Insulin: The Twenty-fifth Anniversary Edition. University of Toronto Press, Toronto.

Brissova, M., Haliyur, R., Saunders, D., Shrestha, S., Dai, C., Blodgett, D.M., Bottino, R., Campbell-Thompson, M., Aramandla, R., Poffenberger, G., Lindner, J., Pan, F.C., von Herrath, M.G., Greiner, D.L., Shultz, L.D., Sanyoura, M., Philipson, L.H., Atkinson, M., Harlan, D.M., Levy, S.E., Prasad, N., Stein, R., Powers, A.C., 2018. $\alpha$ Cell Function and Gene Expression Are Compromised in Type 1 Diabetes. Cell Reports. 22, pp. 26672676. Available from: https://doi.org/10.1016/j.celrep.2018.02.032. [Accessed 14 November 2019].

Broberg, M.B., Dohm, K., 2019. Private fonde betaler en større del af forskningen. JyllandsPosten. Available from: https://jyllands-posten.dk/indland/ECE11549035/Private-fondebetaler-en-st\%C3\%B8rre-del-af-forskningen/. [Accessed 15 September 2019].

CDC, 2020. National Diabetes Statistics Report 2020: Estimates of diabetes and its burden in the United States. Centers for Disease Control and Prevention. Available from:

https://www.cdc.gov/diabetes/pdfs/data/statistics/national-diabetes-statistics-report.pdf. [Accessed 3 March 2020].

CDC, 2019. Health Insurance Coverage: Early Release of Estimates From the National Health Interview Survey, 2014-2017. Centers for Disease Control and Prevention. Available from: https://www.cdc.gov/nchs/nhis/releases.htm. [Accessed 20 March 2020].

Cefalu, W.T., Dawes, D.E., Gavlak, G., Goldman, D., Herman, W.H., Nuys, K.V., Powers, A.C., Taylor, S.I., Yatvin, A.L., 2018a. Insulin Access and Affordability Working Group: Conclusions and Recommendations. Diabetes Care. Available from: https://doi.org/10.2337/dci18-0019. [Accessed 23 December 2019].

Cefalu, W.T., Dawes, D.E., Gavlak, G., Goldman, D., Herman, W.H., Van Nuys, K., Powers, A.C., Taylor, S.I., Yatvin, A.L., 2018b. Erratum. Insulin Access and Affordability Working Group: Conclusions and Recommendations. Diabetes Care. 41(8), pp. 1299 1311. Diabetes Care 41, 1831. https://doi.org/10.2337/dc18-er08

Cleary, E.G., Beierlein, J.M., Khanuja, N.S., McNamee, L.M., Ledley, F.D., 2018. Contribution of NIH funding to new drug approvals 2010-2016. Proceedings of the National Academy of Sciences of the United States of America. 115(10), pp. 2329-2334. Available from: https://doi.org/10.1073/pnas.1715368115. [Accessed 23 December 2019].

Cleary, E.G., Jackson, M., Acevedo, A., Ledley, F.D., 2020. Characterizing the public sector contribution to drug discovery and development: the role of government as a first investor. Institute for New Economic Thinking. Available from: https://www.ineteconomics.org/uploads/papers/Public-sector-contribution-to-drugdiscovery-and-development.pdf. [Accessed 30 March 2020].

DiMasi, J.A., Grabowski, H.G., Hansen, R.W., 2016. Innovation in the pharmaceutical industry: New estimates of R\&D costs. Journal of Health Economics. 47, pp. 20-33. Available from: https://doi.org/10.1016/j.jhealeco.2016.01.012. [Accessed 19 April 2019]. 
Eli Lilly, 2020. Lilly expands insulin affordability options with lower-priced versions of Humalog® Mix $75 / 25^{\mathrm{TM}}$ KwikPen ${ }^{\circledR}$ and Humalog ${ }^{\circledR}$ Junior KwikPen ${ }^{\circledR}$. Eli Lilly and Company. Available from: https://investor.lilly.com/news-releases/news-releasedetails/lilly-expands-insulin-affordability-options-lower-priced. [Accessed 26 January 2020].

Eli Lilly, 2019. Eli Lilly and Company: 2018 Financial Report. Available from: https://investor.lilly.com/financial-information/annual-reports. [Accessed 21 September 2019].

Fried, M., 2018. Prescription for poverty: Drug companies as tax dodgers, price gougers, and influence peddlers. Oxfam International. Available from: https://doi.org/10.1163/22107975_HRD-9824-20180019. [Accessed 21 September 2019].

Friedman, M., 1970. The Social Responsibility of Business Is to Increase Its Profits. The New York Times Magazine. September 13, 1970.

Fuglesten Biniek, J., Johnson, W., 2019. Spending on Individuals with Type 1 Diabetes and the Role of Rapidly Increasing Insulin Prices. Health Care Cost Institute. Available from: https://healthcostinstitute.org/diabetes-and-insulin/spending-on-individuals-with-type-1diabetes-and-the-role-of-rapidly-increasing-insulin-prices. [Accessed 21 September 2019].

Fullerton, B., Siebenhofer, A., Jeitler, K., Horvath, K., Semlitsch, T., Berghold, A., Plank, J., Pieber, T.R., Gerlach, F.M., 2016. Short-acting insulin analogues versus regular human insulin for adults with type 1 diabetes mellitus. Cochrane Database of Systematic Reviews. Available from: https://doi.org/10.1002/14651858.CD012161. [Accessed 28 February 2020].

Goodman, J., 2003. 'Pharmaceutical Industry'. In: Cooter, R., Pickstone, J.V. (Eds.), Companion to Medicine in the Twentieth Century. Taylor \& Francis: Abingdon, United Kingdom. pp. 141-154.

Gotham, D., Barber, M.J., Hill, A., 2018. Production costs and potential prices for biosimilars of human insulin and insulin analogues. BMJ Global Health. 3:e000850. Available from: https://doi.org/10.1136/bmjgh-2018-000850. [Accessed 30 March 2020].

Harris, G., 2001. Cost of Developing New Medicine Swelled To \$802 Million, Research Study Reports. Wall Street Journal. December 1, 2001. Available from: https://www.wsj.com/articles/SB1007336440403996240. [Accessed 30 March 2020].

Herkert, D., Vijayakumar, P., Luo, J., Schwartz, J.I., Rabin, T.L., DeFilippo, E., Lipska, K.J., 2019. Cost-Related Insulin Underuse Among Patients With Diabetes. JAMA Internal Medicine. 179(1), pp. 112-114. Available from: https://doi.org/10.1001/jamainternmed.2018.5008. [Accessed 30 March 2020].

Hernandez, I., San-Juan-Rodriguez, A., Good, C.B., Gellad, W.F., 2020. Changes in List Prices, Net Prices, and Discounts for Branded Drugs in the US, 2007-2018. JAMA 323(9), pp. 854-862. Available from: https://doi.org/10.1001/jama.2020.1012. [Accessed 20 March 2020].

Hopkins, M., Lazonick, W., 2016. The Mismeasure of Mammon: Uses and Abuses of Executive Pay Data. Institute for New Economic Thinking. Available from: https://www.ineteconomics.org/uploads/papers/WP_49_Hopkins_Lazonick_August_29.p df. [Accessed 20 March 2020].

Hopkins, M., Lazonick, W., 2015. Who Invests in the High-Tech Knowledge Base? Institute for New Economic Thinking. Available from: http://dx.doi.org/10.2139/ssrn.2638091 
Hua, X., Carvalho, N., Tew, M., Huang, E.S., Herman, W.H., Clarke, P., 2016. Expenditures and Prices of Antihyperglycemic Medications in the United States: 2002-2013. JAMA 315(1), pp. 1400-1402. Available from: https://doi.org/10.1001/jama.2016.0126. [Accessed 21 September 2019].

Hughes, S.S., 2011. Genentech: The Beginnings of Biotech. University Of Chicago Press, Chicago.

Jaffe, A.B., Fogarty, M.S., Banks, B.A., 1998. Evidence from Patents and Patent Citations on the Impact of NASA and Other Federal Labs on Commercial Innovation. The Journal of Industrial Economics. 46(2), pp.183-205. Available from: https://doi.org/10.1111/14676451.00068. [Accessed 20 September 2019].

Jensen, M.C., 1986. Agency Costs of Free Cash Flow, Corporate Finance, and Takeovers. The American Economic Review. 76(2), pp. 323-329. Available from: https://www-jstororg.ep.fjernadgang.kb.dk/stable/1818789. [Accessed 19 March 2020].

Kaiser Family Foundation, 2019. 2019 Employer Health Benefits Survey. Kaiser Family Foundation. Available from: https://www.kff.org/report-section/ehbs-2019-summary-offindings/. [Accessed 17 January 2020].

Kaiser Family Foundation, 2005. Follow the Pill: Understanding the U.S. Commercial Pharmaceutical Supply Chain. Kaiser Family Foundation. Available from: https://www.kff.org/wp-content/uploads/2013/01/follow-the-pill-understanding-the-u-scommercial-pharmaceutical-supply-chain-report.pdf. [Accessed 2 February 2020].

Kelly, M., 2019. Kelly Introduces MAGIC Act to Make Generic Insulin a Reality. The Website of Congressman Mike Kelly. Available from: https://kelly.house.gov/press-release/kellyintroduces-magic-act-make-generic-insulin-reality. [Accessed 16 January 2020].

Kennedy, J., Morgan, S., 2006. A cross-national study of prescription nonadherence due to cost: Data from the joint Canada-United States survey of health. Clinical Therapeutics. 28, pp. 1217-1224. Available from: https://doi.org/10.1016/j.clinthera.2006.07.009. [Accessed 17 September 2020].

Kuchler, H., 2019. Pharmacy benefit managers face bipartisan criticism. Financial Times. Available from: https://www.ft.com/content/a65d6fcc-5ade-11e9-939a-341f5ada9d40. [Accessed 13 January 2020].

Langreth, R., 2011. Novo Nordisk's Medical Miracle. Forbes. February 9, 2011. Available from: https://www.forbes.com/forbes/2011/0228/features-lars-sorensen-novo-nordisk-medicalmiracle.html\#ae27362291ff. [Accessed 15 February 2020].

Lazonick, W., 2020. Is the most unproductive firm the foundation of the most efficient economy? How Penrosian learning confronts the neoclassical absurdity. The Institute for New Economic Thinking. Available from:

https://www.ineteconomics.org/uploads/papers/WP_111-Lazonick-Penrose-NeoclassicalFallacy.pdf. [Accessed 20 March 2020].

Lazonick, W., 2017. Innovative Enterprise and Sustainable Prosperity. Institute for New Economic Thinking. Available from: https://www.ineteconomics.org/uploads/papers/Lazonick-Innovative-Enterprise-andSustainable-Prosperity-INET-20171010.pdf. [Accessed 21 March 2020].

Lazonick, W., 2016. Innovative Enterprise or Sweatshop Economics?: In Search of Foundations of Economic Analysis. Challenge. 59(2), pp. 65-114. Available from:

https://doi.org/10.1080/05775132.2016.1147297. [Accessed 22 March 2020]. 
Lazonick, W., 2015. Stock buybacks: From retain-and reinvest to downsize-and-distribute. Center for Effective Public Management, Brookings Institution. Available from: https://www.brookings.edu/research/stock-buybacks-from-retain-and-reinvest-todownsize-and-distribute/. [Accessed 25 May 2019].

Lazonick, W., 2014. Profits Without Prosperity: How Stock Buybacks Manipulate the Market and Leave Most Americans Worse Off. Presented at the Annual Conference of the Institute for New Economic Thinking, The Academic-Industry Research Network and University of Massachusetts Lowell, Toronto.

Lazonick, W., 2009. Sustainable Prosperity in the New Economy: Business Organization and High-Tech Employment in the United States. W.E. Upjohn Institute: Michigan, United States.

Lazonick, W., Hopkins, M., Jacobsen, K., Erdem Sakinç, M., Tulum, Ö., 2017a. US Pharma’s Business Model: Why It Is Broken, and How It Can Be Fixed. European Union Horizon 2020, European Union. Available from: http://www.isigrowth.eu/wpcontent/uploads/2017/06/working_paper_2017_13.pdf. [Accessed 30 March 2020].

Lazonick, W., Hopkins, M., Jacobson, K., Sakinç, M.E., Tulum, Ö., 2017b. US Pharma's Financialized Business Model. Institute for New Economic Thinking. Available from: https://www.ineteconomics.org/research/research-papers/us-pharmas-financializedbusiness-model. [Accessed 31 March 2020].

Lazonick, W., Hopkins, M., Jacobson, K., Sakinç, M.E., Tulum, Ö., 2016. Life Sciences? How "Maximizing Shareholder Value" Increases Drug Prices, Restricts Access, and Stifles Innovation. Submission to the United Nations Secretary-General's High-Level Panel on Access to Medicines.

Lazonick, W., Mazzucato, M., 2013. The risk-reward nexus in the innovation-inequality relationship: who takes the risks? Who gets the rewards? Industrial Corporate Change. 22(4), pp. 1093-1128. Available from: https://doi.org/10.1093/icc/dtt019. [Accessed 22 March 2020].

Lazonick, W., O’Sullivan, M., 2000. Maximizing shareholder value: a new ideology for corporate governance. Economy and Society. 29(1), pp. 13-35. Available from: https://doi.org/10.1080/030851400360541. [Accessed 12 April 2019].

Lazonick, W., Shin, J.-S., 2020. Predatory Value Extraction: How the Looting of the Business Enterprise Became the US Norm and How Sustainable Prosperity Can Be Restored. Oxford University Press: New York, United States.

Lazonick, W., Tulum, Ö., 2011. US biopharmaceutical finance and the sustainability of the biotech business model. Research Policy. 40(9), pp. 1170-1187. Available from: https://doi.org/10.1016/j.respol.2011.05.021. [Accessed 21 September 2019].

Lazonick, W., Tulum, Ö., Hopkins, M., Sakinç, M.E., Jacobsen, K., 2019. Financialization of the U.S. Pharmaceutical Industry. Institute for New Economic Thinking. Available from: https://www.ineteconomics.org/perspectives/blog/financialization-us-pharma-industry. [Accessed 13 January 2020].

Lee, B., 2019. How Much Does Insulin Cost? Here's How 23 Brands Compare. GoodRx. Lilly Endowment Inc., 2020. About us. Available from: https://lillyendowment.org/about/. [Accessed 9 March 2020].

Link, A.N., Siegel, D.S., Van Fleet, D.D., 2011. Public science and public innovation: Assessing the relationship between patenting at U.S. National Laboratories and the Bayh-Dole Act. 
Research Policy. 40(8), pp. 1094-1099. Available from:

https://doi.org/10.1016/j.respol.2011.05.011. [Accessed 31 March 2020].

Loftus, P., Roland, 2016. Insulin Prices Soar While Drugmakers' Share Stays Flat. Wall Street Journal. Available from: https://www.wsj.com/articles/insulin-prices-soar-whiledrugmakers-share-stays-flat-1475876764. [Accessed 20 November 2019].

Malerba, F., Orsenigo, L., 2015. The evolution of the pharmaceutical industry. Business History. 57(1), pp. 664-687. Available from: https://doi.org/10.1080/00076791.2014.975119. [Accessed 6 May 2019].

Mattner, J., Mohammed, J.P., Fusakio, M.E., Giessler, C., Hackstein, C.-P., Opoka, R., Wrage, M., Schey, R., Clark, J., Fraser, H.I., Rainbow, D.B., Wicker, L.S., 2019. Genetic and functional data identifying Cd101 as a type 1 diabetes (T1D) susceptibility gene in nonobese diabetic (NOD) mice. PLoS Genetics. 15(1):e1008178. Available from: https://doi.org/10.1371/journal.pgen.1008178. [Accessed 21 March 2019].

Mazzucato, M., 2018. The Entrepreneurial State: Debunking Public vs. Private Sector Myths. Penguin: London, United Kingdom.

Milford, P., 2012. Mylan, Pfizer Reach Epinephrine-Pen Settlement With Teva. Bloomberg. Available from: https://www.bloomberg.com/news/articles/2012-04-26/mylan-pfizerannounce-epinephrine-pen-settlement-with-teva-1-. [Accessed 30 March 2020].

Millman, J., 2014. Does it really cost $\$ 2.6$ billion to develop a new drug? Washington Post. Available from: https://www.washingtonpost.com/news/wonk/wp/2014/11/18/does-itreally-cost-2-6-billion-to-develop-a-new-drug/. [Accessed 26 November 2019].

Mowery, D.C., Nelson, R.R., Sampat, B.N., Ziedonis, A.A., 2004. Ivory Tower and Industrial Innovation: University-Industry Technology Transfer Before and after the Bayh-Dole Act. Stanford University Press: Palo Alto, United States.

Naci, H., Carter, A.W., Mossialos, E., 2015. Why the drug development pipeline is not delivering better medicines. BMJ. 351:h5542. Available from: https://doi.org/10.1136/bmj.h5542. [Accessed 25 November 2019].

NICE, 2020. Type 2 diabetes in adults: management. NICE Guidance. Available from: https://www.nice.org.uk/guidance/ng28. [Accessed 25 March 2020].

Novo Holdings, 2020. Investments. Available from: https://www.novoholdings.dk/investments/. [Accessed 10 February 2020].

Novo Nordisk, 2020. Novo Nordisk Annual Report 2019. Available from: https://www.novonordisk.com/annual-report.html. [Accessed 30 March 2020].

Novo Nordisk, 2019a. Novo Nordisk launching additional US insulin affordability offerings in January 2020. Available from: http://www.novonordisk-us.com/media/newsreleases.html. [Accessed 26 January 2020].

Novo Nordisk, 2019b. Novo Nordisk Annual Report 2018. Available from: https://www.novonordisk.com/content/dam/Denmark/HQ/investors/irmaterial/annual_rep ort/2019/NN-AR18_UK_Online.pdf. [Accessed 10 February 2020].

Novo Nordisk, 2019c. Novo Nordisk - A Focused Healthcare Company. Available from: https://www.novonordisk.com/content/dam/Denmark/HQ/investors/irmaterial/investor_pr esentations/2019/20190201_Q4\%202018\%20roadshow\%20presentation.pdf. [Accessed 10 February 2020].

Novo Nordisk Fonden, 2019. The Grant Report 2018. Available from: https://novonordiskfonden.dk/wp-content/uploads/UK_GRANT_REPORT_2018.pdf. [Accessed 10 February 2020]. 
Obitsø, O., 2018. Forskningen styres i stigende grad af politikere og store virksomheder. Magisterbladet. Available from:

https://www.magisterbladet.dk/aktuelt/2018/oktober/forskningen-styres-i-stigende-gradaf-politikere-og-store-virksomheder. [Accessed 30 January 2020].

Owen, G., Hopkins, M.M., 2016. Science, the State and the City: Britain's Struggle to Succeed in Biotechnology. Oxford University Press: Oxford, United Kingdom.

Penrose, E., 2009. The Theory of the Growth of the Firm. Fourth Edition. Oxford University Press: New York.

Pesenacker, A.M., Chen, V., Gillies, J., Speake, C., Marwaha, A.K., Sun, A., Chow, S., Tan, R., Elliott, T., Dutz, J.P., Tebbutt, S.J., Levings, M.K., 2019. Treg gene signatures predict and measure type 1 diabetes trajectory. JCI Insight. 4(1). Available from: https://doi.org/10.1172/jci.insight.123879. [Accessed 21 March 2020].

Pharmaceutical Technology, 2016. The world's top selling diabetes drugs. Pharmaceutical Technology. Available from: https://www.pharmaceuticaltechnology.com/features/featurethe-worlds-top-selling-diabetes-drugs-4852441/. [Accessed 20 March 2020].

PhRMA, 2019. Biopharmaceuticals in Perspective. Pharmaceutical Research and Manufacturers of America. Available from: http://phrmadocs.phrma.org/files/dmfile/PhRMA_2019_ChartPack_Final.pdf. [Accessed 30 March 2020].

Pisano, G.P., 2006. Science Business: The Promise, the Reality, and the Future of Biotech. Harvard Business School Press: Massachusetts, United States.

Pollack, A., 2016. Mylan Raised EpiPen's Price Before the Expected Arrival of a Generic. The New York Times. Available from: https://www.nytimes.com/2016/08/25/business/mylanraised-epipens-price-before-the-expected-arrival-of-a-generic.html. [Accessed 12 April 2019].

Pollack, A., 2015. Drug Goes From \$13.50 a Tablet to \$750, Overnight. The New York Times. Available from: https:/www.nytimes.com/2015/09/21/business/a-huge-overnightincrease-in-a-drugs-price-raises-protests.html. [Accessed 12 April 2019].

Ramsey, L., 2017. The prices for life-saving diabetes medications have increased again. Business Insider. May 15, 2017. Available from: https://finance.yahoo.com/news/prices-lifesaving-diabetes-medications-192331334.html. [Accessed 30 March 2020].

Ramsey, L., 2016a. A 93-year-old drug that can cost more than a mortgage payment tells us everything that's wrong with American healthcare. Business Insider. September 16, 2016. Available from: https://www.businessinsider.my/insulin-prices-increase-2016-9. [Accessed 30 March 2020].

Ramsey, L., 2016b. There's something odd about the way insulin prices change. Business Insider Singapore. Available from: https://www.businessinsider.sg/rising-insulin-prices-trackcompetitors-closely-2016-9/. [Accessed 12 May 2019].

Randall, L., Begovic, J., Hudson, M., Smiley, D., Peng, L., Pitre, N., Umpierrez, D., Umpierrez, G., 2011. Recurrent diabetic ketoacidosis in inner-city minority patients: behavioral, socioeconomic, and psychosocial factors. Diabetes Care. 34(9), pp. 1891-1896. Available from: https://doi.org/10.2337/dc11-0701. [Accessed 12 September 2019].

Reuters, 2018. Teva prices EpiPen generic at \$300, same price as Mylan generic. Reuters. November 27, 2018. Available from: https:/www.reuters.com/article/us-teva-pharm-ind- 
epipen/teva-prices-epipen-generic-at-300-same-price-as-mylan-genericidUSKCN1NW1Q5. [Accessed 12 April 2019].

Rockoff, J.D., 2016. Mylan Faces Scrutiny Over EpiPen Price Increases. Wall Street Journal. August 24, 2016. Available from: https:/www.wsj.com/articles/mylan-faces-scrutinyover-epipen-price-increases-1472074823. [Accessed 12 April 2019].

Roy, V., King, L., 2016. Betting on hepatitis C: how financial speculation in drug development influences access to medicines. BMJ. 354:i3718. Available from: https://doi.org/10.1136/bmj.i3718. [Accessed 29 April 2019].

Sanders, B., 2019. S.102 - 116th Congress (2019-2020): Prescription Drug Price Relief Act of 2019.

Sarnak, D.O., Squires, D., Bishop, S., 2017. Prescription Drug Spending Why Is the U.S. an Outlier? The Commonwealth Fund. Available from: https://www.commonwealthfund.org/publications/issue-briefs/2017/oct/payingprescription-drugs-around-world-why-us-outlier. [Accessed 23 May 2019].

Scannell, J.W., Blanckley, A., Boldon, H., Warrington, B., 2012. Diagnosing the decline in pharmaceutical R\&D efficiency. Nature Reviews Drug Discovery. 11(1), pp. 191-200. Available from: https://doi.org/10.1038/nrd3681. [Accessed 12 September 2019].

Schuster, L., 2000. 'The Shareholder Value and Stakeholder Discussion: An International Overview'. In: Schuster, L. (Ed.), Shareholder Value Management in Banks. Palgrave Macmillan: London, United Kingdom. pp. 3-12.

Siegel, D.S., Veugelers, R., Wright, M., 2007. Technology transfer offices and commercialization of university intellectual property: performance and policy implications. Oxford Review of Economic Policy. 23(4), pp. 640-660. Available from: https://doi.org/10.1093/oxrep/grm036. [Accessed 20 March 2020].

Søndergaard, J., Vach, K., Kragstrup, J., Andersen, M., 2009. Impact of pharmaceutical representative visits on GPs' drug preferences. Family Practice. 26(3), pp. 204-209. Available from: https://doi.org/10.1093/fampra/cmp010. [Accessed 20 March 2020].

Sood, N., Shih, T., Van Nuys, K., Goldman, D., 2017. The Flow of Money Through the Pharmaceutical Distribution System. USC Schaeffer Center. Available from: https://healthpolicy.usc.edu/wp-content/uploads/2017/06/USC_Flow-ofMoneyWhitePaper_Final_Spreads.pdf. [Accessed 20 March 2020].

Strongin, R.J., 1999. The ABCs of PBMs. National Health Policy Forum. 749(1), pp. 1-12. Available from: https://www.ncbi.nlm.nih.gov/pubmed/10848111. [Accessed $31 \mathrm{March}$ 2020].

T1 International, 2019. Costs and rationing of insulin and diabetes supplies: findings from the 2018 T1International patient survey. Available from: https://www.tlinternational.com/media/assets/file/T1International_Report__Costs_and_Rationing_of_Insulin__Diabetes_Supplies_2.pdf. [Accessed $31 \mathrm{March}$ 2020].

Thomsen, S., Poulsen, T., Børsting, C., Kuhn, J., 2018. Industrial foundations as long-term owners. Corporate Governance. 26(3), pp. 180-196. Available from: https://doi.org/10.1111/corg.12236. [Accessed 31 March 2020].

Thursby, J.G., Thursby, M.C., 2011. Has the Bayh-Dole act compromised basic research? Research Policy. 40(8), pp. 1077-1083. Available from: https://doi.org/10.1016/j.respol.2011.05.009. [Accessed 31 March 2020]. 
Tolbert, J., Orgera, K., Singer, N. Key Facts about the Uninsured Population. The Henry J. Kaiser Family Foundation. Available from: https://www.kff.org/uninsured/issuebrief/key-facts-about-the-uninsured-population/. [Accessed 14 December 2019].

Torjesen, I., 2015. Drug development: the journey of a medicine from lab to shelf. The Pharmaceutical Journal. May 12, 2015. Available from: https://www.pharmaceuticaljournal.com/publications/tomorrows-pharmacist/drug-development-the-journey-of-amedicine-from-lab-to-shelf/20068196.article?firstPass=false

True, S. 2019. What's the Latest on Medicare Drug Price Negotiations? The Henry J. Kaiser Family Foundation. Available from: https://www.kff.org/medicare/issue-brief/whats-thelatest-on-medicare-drug-price-negotiations/. [Accessed 13 January 2020].

Tulum, Ö., 2018. Innovation and financialization in the U.S. biopharmaceutical industry. [Doctoral thesis]. University of Ljubljana: Ljubljana, Slovenia.

Tulum, Ö., Lazonick, W., 2018. Financialized Corporations in a National Innovation System: The U.S. Pharmaceutical Industry. International Journal of Political Economy. 47(3-4), pp. 281-316. Available from: https://doi.org/10.1080/08911916.2018.1549842. [Accessed 31 March 2020].

UCL Institute for Innovation and Public Purpose, 2018. The people's prescription: Re-imagining health innovation to deliver public value. IIPP, Global Justice Now, Just Treatment, STOPAIDS. Available from: https://www.ucl.ac.uk/bartlett/publicpurpose/publications/2018/oct/peoples-prescription. [Accessed 29 May 2019].

United States Senate, 2019. Inaccessible Insulin: The Broken Promise of Eli Lilly's Authorized Generic. The Offices of U.S. Senator Elizabeth Warren and U.S. Senator Richard Blumenthal. Available from: https://www.warren.senate.gov/oversight/reports/senatorswarren-and-blumenthal-release-investigation-revealing-diabetes-patients-lack-of-accessto-lower-priced-insulin. [Accessed 14 January 2020].

U.S. Government Accountability Office, 2016. Generic Drugs Under Medicare: Part D Generic Drug Prices Declined Overall, but Some Had Extraordinary Price Increases. Available from: https://www.gao.gov/assets/680/679022.pdf. [Accessed 31 March 2020].

Wapner, J., 2017. Understanding the hidden villain of Big Pharma: pharmacy benefit managers. Newsweek. March 17, 2017. Available from: https://www.newsweek.com/big-pharmavillain-pbm-569980. [Accessed 1 March 2020]. 